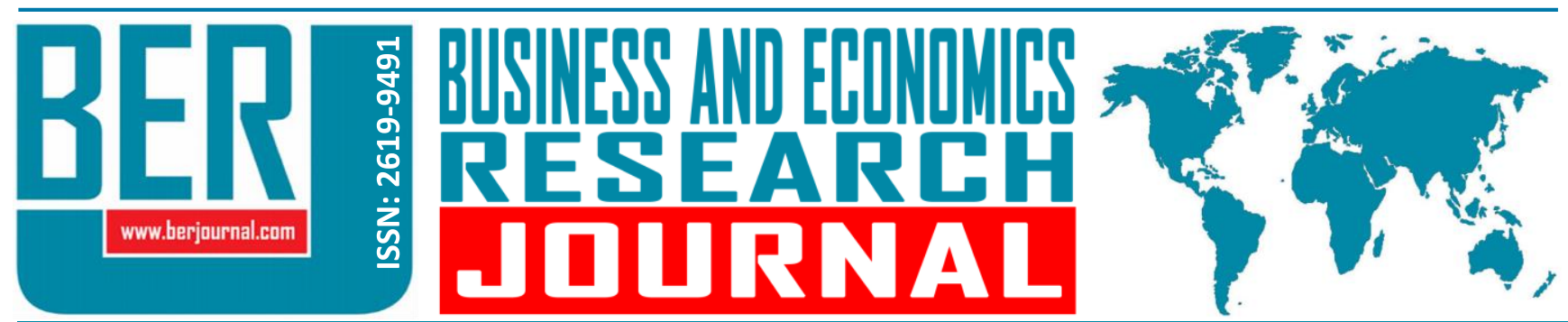

Business and Economics Research Journal Vol. 11, No. 3, 2020, pp. 713-734 doi: 10.20409/berj.2020.270

\section{Konut Fiyatlarının Mekânsal Kantil Regresyon Yaklaşımına Göre Modellenmesi: Denizli İli Örneği ${ }^{1}$}

\begin{abstract}
Sinem Guler Kangalli Uyar ${ }^{\mathrm{a}}$, Nur Duygu Keten ${ }^{\mathrm{b}}$
Öz: Çalışmanın amacı, konut satış fiyatları ve özellikleri arasındaki ilişkileri hedonik fiyat teorisi çerçevesinde mekânsal kantil regresyon yaklaşımı ile incelemektir. Mayıs-Haziran 2019 döneminde Denizli konut piyasası için merkez ilçelerden 3666 adet satılık konut verisi elde edilerek, Denizli konut piyasasının talep yönüne ilişkin bilgilerin sağlanması amaçlanmıştır. Mekânsal kantil regresyon modelinin tahmin sonuçlarına göre, konut fiyatlarının en yüksek ve en düşük olduğu dilimler için yapısal, fiziksel ve mekânsal konut özelliklerinin konut fiyatları üzerindeki etkileri farklılaşmaktadır. Çalışmanın dikkat çekici bulgularından biri de konut satış fiyatları dağılımının farklı dilimleri için komşu konutların fiyatlarındaki artışın konut fiyatlarını farklı oranlarda arttırmasıdır. Komşu konumlardaki konutların fiyatları en fazla konut fiyatlarının en düşük olduğu \%25'lik dilim için konut fiyatlarını arttırmaktadır. Sonuç olarak, konut fiyatlarının farklı dilimleri için konut fiyatlarını artıran ve azaltan özelliklerin belirlenmesi, farklı gelir düzeylerine sahip hanelerin konut tercihleri hakkında dolaylı olarak bilgi sağlayabilir.
\end{abstract}

\section{Modelling of Housing Prices by Spatial Quantile Regression Approach: A Case of Denizli Province}

Abstract: The aim of the study is to examine the relationships between housing prices and characteristics by spatial quantile regression approach within the framework of hedonic price theory. In the period of May-June 2019, 3666 units of housing data for sale were obtained from the central districts for the Denizli housing market and it was aimed to provide information regarding the demand direction of the Denizli housing market. According to the estimation results of spatial quantile regression, the effects of structural, physical and locational housing characteristics on the housing prices change for the quantiles with the highest and lowest housing prices. One of the remarkable findings of the study is that an increment in the prices of neighboring houses for different segments of the distribution of housing asking prices increases the housing prices at different rates. The housing prices in neighbor locations most affect positively the housing prices at the bottom of 25th quartile. Consequently, determining the characteristics that increase and decrease the housing prices for different segments might implicitly provide information about the housing preferences of households with different income levels.

Anahtar Sözcükler: Hedonik Fiyat Teorisi, Mekânsal Kantil Regresyon, iki Aşamalı Kantil Regresyon Yöntemi, Konut Piyasası, Denizli

JEL: C21, R31, R32

$\begin{array}{ll}\text { Geliş } & : 27 \text { Mart } 2020 \\ \text { Düzeltme } & : 12 \text { Mayıs } 2020 \\ \text { Kabul } & : 03 \text { Haziran } 2020 \\ \text { Tür } & : \text { Araştırma }\end{array}$

Keywords: Hedonic Price Theory, Spatial Quantile Regression, Two-Stage Quantile Regression, Housing Market, Denizli

JEL: C21, R31, R32

$\begin{array}{ll}\text { Received } & : 27 \text { March } 2020 \\ \text { Revised } & : 12 \text { May } 2020 \\ \text { Accepted } & : \text { 03 June } 2020 \\ \text { Type } & : \text { Research }\end{array}$

Cite this article as: Kangalli-Uyar, S. G., \& Keten, N. D. (2020). Konut fiyatlarının mekânsal kantil regresyon yaklașımına göre modellenmesi: Denizli ili örneği. Business and Economics Research Journal, 11(3), 713-734.

The current issue and archive of this Journal is available at: www.berjournal.com

a Assist. Prof., PhD., Pamukkale University, Faculty of Economics and Administrative Science, Department of Econometrics, Denizli, Turkiye, skangalli@pau.edu.tr (ORCID ID: 0000-0003-3694-150X)

b Pamukkale University, Institute of Social Sciences, Department of Econometrics, Denizli, Turkiye, duyguketen26@gmail.com (ORCID ID: 0000-0003-3665-3866) 


\section{Giriş}

Konutun birbirinden farklı yapısal, fiziksel, mekânsal ve komşuluk özelliklerine sahip olması heterojen bir ürün olmasına neden olur (Rosen, 1974: 34-37). Dolayısıyla konut piyasası da heterojen bir yapıya sahiptir (Rosen, 1974: 34-55; Lancester, 1966: 132-157). Bu özellikleri nedeniyle konut fiyatlarının tahmin edilmesi ve belirlenmesi zorlaşmaktadır (Kangallı Uyar ve Yayla, 2016: 327). Konut fiyatlarının tahmininde mal ya da hizmetlerin heterojen olması varsayımına dayalı olan ve literatürde de sıklıkla ele alınan "Hedonik Fiyat Teorisi" (HFT) olarak da bilinen "Hedonik Fiyat Yaklaşımı" (HFY) kullanılmaktadır (Straszheim, 1974: 23-25).

Hedonik Fiyat Yaklaşımı (HFY), mal ya da hizmete ilişkin özelliklerin her birinin fiyat üzerindeki etkisini belirlemektedir. Bu yaklaşım, bir mal ya da hizmetin fiyatının malın ya da hizmetin sahip olduğu karakteristik özelliklere göre nasıl değiştiğini gösterir. HFY ile malın ya da hizmetin kendisinin fiyatı değil sahip olduğu özelliklerin fiyatı tahmin edilir. Böylece, konutun özellikleri ile fiyatı arasındaki ilişkilerin tahmininde HFY kullanılabilmektedir (Bourassa, Cantoni ve Hoesli, 2007: 144-145).

Konut satış fiyatının en önemli belirleyicilerinden biri de mekânsal bağımlılıktır. Mekânsal bağımlılık, bir konumda gözlemlenen değer ile komşu konumda gözlemlenen değer arasındaki ilişkidir ve mekânsal bağımlıık sonucu, konutların satış fiyatı yakın konumda yer alan konutların satış fiyatına benzeyebilir. Bu nedenle, konut satış fiyatlarına ilişkin tahminler yapılırken mekân bağımlılık etkisi dikkate alınmalıdır. Mekân bağımlılığın dikkate alındığı regresyon modelleri mekânsal regresyon modelleri olarak adlandırılır. Ancak, standart mekânsal ekonometrik modeller veri setinin uç değerler içermesi sonucu hata terimlerine ilişkin sabit varyans ve Normal dağılım varsayımlarının sağlanamaması durumunda yetersiz kalmaktadır. Bu durumda, standart mekânsal ekonometrik modellere alternatif olarak mekânsal kantil regresyon modeli (SQR) kullanılabilir. Ayrıca, mekânsal kantil regresyon yaklaşımı ile bağımlı değişkenin koşullu dağılımının farklı dilimleri (kantilleri) için değişen ilişkiler incelenebilir. Dolayısıyla, konut satış fiyatlarının koşullu dağııııının farklı dilimleri için konut satış fiyatları ile konut özellikleri arasındaki ilişkilerin değişimi mekânsal kantil regresyon yöntemi kullanılarak gözlemlenebilir. Standart mekânsal ekonometrik modellerde ise mekânsal kantil regresyon yaklaşımının aksine konut fiyatlarının en yüksek ve en düşük olduğu dilimler için konut özelliklerinin konut fiyatları üzerindeki etkilerinin aynı olduğu varsayılmaktadır.

Bu çalışmada Denizli konut piyasası için konut satış fiyatları ve özellikleri arasındaki ilişkiler HFT'ye göre standart mekânsal ekonometrik modeller ve mekânsal kantil regresyon yaklaşımı ile incelenmiştir. Çalışmada Denizli konut piyasasının tercih edilmesinin nedeni, Denizli'nin Ege ve Akdeniz Bölgesi arasında bir geçit pozisyonuna sahip olması, hanehalkı sayısında meydana gelen artışlar nedeniyle konut ihtiyacının artması, tekstil ürünleri, değerli maden ürünleri gibi dünya çapındaki pek çok markaya ürün imalâtı yapan bir ticaret merkezi olması, ayrıca son zamanlarda iç ve dış göç almasıdır. Denizli'nin merkez ilçeleri Denizli konut piyasasının alt piyasalarını oluşturmaktadır ve alt piyasaların her birinde konut satış fiyatları farklı arz ve talep koşulları nedeniyle farklılık göstermektedir. Heterojen yapıya sahip Denizli konut piyasasına ilişkin hedonik konut fiyatlama çalışmalarından farklı olarak bu çalışmada mekânsal bağımlılık etkisi dikkate alınarak, konut fiyatlarının farklı dilimleri için konut fiyatları ve özellikleri arasındaki ilişkilerin değişimi mekânsal kantil regresyon yaklaşımı ile incelenmiştir. Bu analizler sonucunda, mekânsal bağımlılık etkisi dikkate alınarak Denizli ilinde konut satış fiyatlarının en yüksek ve en düşük dilimleri için konut satış fiyatlarını hangi konut özelliklerinin ne yönde ve ne derecede etkilediğine dair bilgiler elde edilmiştir.

\section{Literatür Taraması}

Hedonik konut fiyat yaklaşımı ile ilgili ulusal ve uluslararası olmak üzere literatürde çok sayıda çalışma mevcuttur. Literatürde yer alan bu çalışmalarda konut özelliklerinin genel olarak yapısal, mekânsal ve komşuluk özellikleri olmak üzere üç kategoriye ayrıldığı gözlemlenmiştir. İncelenen çalışmalarda ele alınan konut özellikleri şehirden şehire, ülkeden ülkeye ve bölgeden bölgeye farklılık göstermektedir. Aynı şehir, ülke ya da bölge için yapılan çalışmalarda örneklem döneminin, örnekleme dâhil edilen konut türünün ve kullanılan yöntemin değişmesi sonucunda da konut fiyatları ve konut özellikleri arasındaki ilişkiler önemli ölçüde farklılık gösterebilmektedir. Özellikle uluslararası hedonik fiyat çalışmaları literatürde geniş bir yer kaplamaktadır ve bu çalışmaların çoğunlukla orijinal olmasını sağlayan en önemli etken kullandıkları model 
ve yöntemdir. Bu nedenle literatür incelemesinde çalışmalarda kullanılan model ve yöntem farklııkları üzerine odaklanılacaktır.

Tablo 1. Uluslararası Hedonik Konut Fiyatlama Çalışmaları

\begin{tabular}{|c|c|c|c|c|c|c|}
\hline Çalışma & Konut Piyasası & $\begin{array}{l}\text { Örneklem } \\
\text { Dönemi }\end{array}$ & $\begin{array}{l}\text { Gözlem } \\
\text { Sayısı }\end{array}$ & $\begin{array}{l}\text { Konut Özellikleri } \\
\text { ve Değişken } \\
\text { Sayısı }\end{array}$ & Model & Yöntem \\
\hline $\begin{array}{l}\text { Anglin ve } \\
\text { Gençay } \\
(1996)\end{array}$ & $\begin{array}{l}\text { Windsor, } \\
\text { Kanada }\end{array}$ & 1987 & 546 & $\begin{array}{l}\text { Yapısal, Fiziksel ve } \\
\text { Komşuluk } \\
\text { Özellikleri (11 } \\
\text { değişken) }\end{array}$ & $\begin{array}{l}\text { Log-Lineer } \\
\text { Model, } \\
\text { Yarıparametrik } \\
\text { Model }\end{array}$ & $\begin{array}{l}\text { EKK Yöntemi, } \\
\text { Yarıparametrik } \\
\text { Yöntem }\end{array}$ \\
\hline $\begin{array}{l}\text { Haurin ve } \\
\text { Brasington } \\
(1996)\end{array}$ & Ohio, ABD & 1991 & 45.236 & $\begin{array}{l}\text { Yapısal, Fiziksel ve } \\
\text { Komşuluk } \\
\text { Özellikleri (26 } \\
\text { değişken) }\end{array}$ & Log-Lineer Model & $\begin{array}{l}\text { Genelleştirilmiş } \\
\text { EKK (GEKK) } \\
\text { Yöntemi }\end{array}$ \\
\hline $\begin{array}{l}\text { Basu ve } \\
\text { Thibodeau } \\
\text { (1998) }\end{array}$ & $\begin{array}{l}\text { Dallas, Teksas } \\
\text { ABD }\end{array}$ & $\begin{array}{l}\text { 1991:4- } \\
\text { 1993:1 }\end{array}$ & 5.000 & $\begin{array}{l}\text { Yapısal ve Fiziksel } \\
\text { Özellikler (15 } \\
\text { değişken) }\end{array}$ & Log-Lineer Model & $\begin{array}{l}\text { EKK Yöntemi, } \\
\text { Genelleştirilmiş } \\
\text { EKK Yöntemi }\end{array}$ \\
\hline $\begin{array}{l}\text { Pavlov } \\
(2000)\end{array}$ & $\begin{array}{l}\text { Los Angeles, } \\
\text { ABD }\end{array}$ & $\begin{array}{l}1 \text { Nisan } \\
1997-30 \\
\text { Eylül } 1997\end{array}$ & 3.000 & $\begin{array}{l}\text { Yapısal, Fiziksel ve } \\
\text { Mekânsal } \\
\text { Özellikler (4 } \\
\text { değişken) }\end{array}$ & $\begin{array}{l}\text { Mekâna Göre } \\
\text { Değişen } \\
\text { Katsayılar (SVC) } \\
\text { Modeli }\end{array}$ & $\begin{array}{l}\text { Yarıparametrik } \\
\text { Yöntem }\end{array}$ \\
\hline $\begin{array}{l}\text { Fletcher, } \\
\text { Gallimore } \\
\text { ve Mangan } \\
(2000)\end{array}$ & İngiltere & 1994 & 1.400 & $\begin{array}{l}\text { Yapısal ve Fiziksel } \\
\text { Özellikler (51 } \\
\text { değişken) }\end{array}$ & Log-Lineer Model & $\begin{array}{l}\text { EKK Yöntemi, } \\
\text { GEKK Yöntemi }\end{array}$ \\
\hline $\begin{array}{l}\text { Leishman } \\
\text { (2001) }\end{array}$ & $\begin{array}{l}\text { Glasgow, } \\
\text { İngiltere }\end{array}$ & 1989-1992 & 1.155 & $\begin{array}{l}\text { Fiziksel Özellikler } \\
\text { ve Zaman-Kukla } \\
\text { Değişkenleri (29 } \\
\text { değişken) }\end{array}$ & Lineer Model & EKK Yöntemi \\
\hline $\begin{array}{l}\text { Wen, } \\
\text { Sheng-hua } \\
\text { ve Xiao-yu } \\
\text { (2005) }\end{array}$ & Hangzhou, Çin & $\begin{array}{l}\text { Ocak 2003- } \\
\text { Haziran } \\
2003\end{array}$ & 2.473 & $\begin{array}{l}\text { Yapısal, Fiziksel, } \\
\text { Mekânsal } \\
\text { Özellikler, Satış } \\
\text { Özellikleri (18 } \\
\text { değişken) }\end{array}$ & Lineer Model & EKK Yöntemi \\
\hline $\begin{array}{l}\text { Kestens, } \\
\text { Thériault ve } \\
\text { Des Rosiers } \\
\text { (2006) }\end{array}$ & $\begin{array}{l}\text { Quebec, } \\
\text { Kanada }\end{array}$ & $1993-2001$ & 761 & $\begin{array}{l}\text { Yapısal, Fiziksel, } \\
\text { Mekânsal } \\
\text { Özellikler, } \\
\text { Komşuluk ve } \\
\text { Hanehalkının } \\
\text { Sosyoekonomik } \\
\text { Özellikleri (53 } \\
\text { değişken) }\end{array}$ & $\begin{array}{l}\text { Mekânsal } \\
\text { Otoregresif } \\
\text { Model, Coğrafi } \\
\text { Ağırlıklı } \\
\text { Regresyon (GWR) } \\
\text { Modeli }\end{array}$ & $\begin{array}{l}\text { Maksimum } \\
\text { Olabilirlik (ML) } \\
\text { Yöntemi, } \\
\text { Yarıparametrik } \\
\text { Yöntem }\end{array}$ \\
\hline $\begin{array}{l}\text { Martins- } \\
\text { Filho ve Bin } \\
(2005)\end{array}$ & Oregon, ABD & $\begin{array}{l}\text { Haziran } \\
\text { 1992- } \\
\text { Mayıs } 1994\end{array}$ & 1.000 & $\begin{array}{l}\text { Yapısal, Fiziksel ve } \\
\text { Mekânsal } \\
\text { Özellikler (12 } \\
\text { değişken) }\end{array}$ & $\begin{array}{l}\text { Log-Lineer } \\
\text { Model, Toplamsal } \\
\text { Regresyon } \\
\text { Modeli }\end{array}$ & $\begin{array}{l}\text { EKK Yöntemi, } \\
\text { Parametrik } \\
\text { Olmayan Yöntem }\end{array}$ \\
\hline $\begin{array}{l}\text { Anselin ve } \\
\text { Le Gallo } \\
(2006)\end{array}$ & $\begin{array}{l}\text { Los Angeles, } \\
\text { Riverside, San } \\
\text { Bernardino ve } \\
\text { Orange, ABD }\end{array}$ & 1999 & 115.732 & $\begin{array}{l}\text { Yapısal, Fiziksel, } \\
\text { Mekânsal } \\
\text { Özellikler ve } \\
\text { Komşuluk } \\
\text { Özellikleri (19 } \\
\text { değişken) }\end{array}$ & $\begin{array}{l}\text { Log-Lineer } \\
\text { Model, Mekânsal } \\
\text { Modeller }\end{array}$ & $\begin{array}{l}\text { EKK Yöntemi, } \\
\text { Araç Değişken } \\
\text { Yöntemi, Robust } \\
\text { Araç Değişken } \\
\text { Yöntemi, ML } \\
\text { Yöntemi, } \\
\text { Genelleştirilmiş } \\
\text { Momentler } \\
\text { Yöntemi }\end{array}$ \\
\hline
\end{tabular}


Tablo 1. Uluslararası Hedonik Konut Fiyatlama Çalışmaları (Devam)

\begin{tabular}{|c|c|c|c|c|c|c|}
\hline $\begin{array}{l}\text { Farber ve } \\
\text { Yeates } \\
(2006)\end{array}$ & $\begin{array}{l}\text { Toronto, } \\
\text { Kanada }\end{array}$ & $\begin{array}{l}\text { Temmuz } \\
\text { 2000- } \\
\text { Haziran } \\
2001\end{array}$ & 19.007 & $\begin{array}{l}\text { Yapısal, Fiziksel, } \\
\text { Mekânsal } \\
\text { Özellikler ve } \\
\text { Komşuluk } \\
\text { Özellikleri (9 } \\
\text { değişken) }\end{array}$ & $\begin{array}{l}\text { Log-Lineer } \\
\text { Model, Mekânsal } \\
\text { Otoregresif } \\
\text { Model, GWR } \\
\text { Modeli, Hareketli } \\
\text { Pencere } \\
\text { Regresyon } \\
\text { (MWR) Modeli }\end{array}$ & $\begin{array}{l}\text { EKK Yöntemi, ML } \\
\text { Yöntemi, } \\
\text { Yarıparametrik } \\
\text { Yöntem }\end{array}$ \\
\hline $\begin{array}{l}\text { Anselin ve } \\
\text { Lozano- } \\
\text { Gracia } \\
(2008)\end{array}$ & $\begin{array}{l}\text { Güney } \\
\text { Kaliforniya, } \\
\text { ABD }\end{array}$ & 1999 & 100.000 & $\begin{array}{l}\text { Yapısal, Fiziksel, } \\
\text { Mekânsal } \\
\text { Özellikler ve } \\
\text { Komşuluk } \\
\text { Özellikleri (26 } \\
\text { değişken) }\end{array}$ & $\begin{array}{l}\text { Log-Lineer } \\
\text { Model, Mekânsal } \\
\text { Gecikme Modeli }\end{array}$ & $\begin{array}{l}\text { EKK Yöntemi, } \\
\text { Araç Değişken } \\
\text { Yöntemi, } \\
\text { Maksimum } \\
\text { Olabilirlik } \\
\text { Yöntemi, } \\
\text { Mekânsal İki } \\
\text { Aşamalı EKK } \\
\text { Yöntemi }\end{array}$ \\
\hline $\begin{array}{l}\text { Zietz, Zietz } \\
\text { ve Sirmans } \\
(2008)\end{array}$ & $\begin{array}{l}\text { Orem/Provo, } \\
\text { Utah, ABD }\end{array}$ & $1999-2000$ & 1.366 & $\begin{array}{l}\text { Yapısal ve Fiziksel } \\
\text { Özellikler ( } 31 \\
\text { değişken) }\end{array}$ & $\begin{array}{l}\text { Log-Lineer } \\
\text { Model, Mekânsal } \\
\text { Gecikme Modeli, } \\
\text { Kantil Regresyon } \\
\text { Modeli }\end{array}$ & $\begin{array}{l}\text { EKK Yöntemi, iki } \\
\text { Aşamalı EKK } \\
\text { Yöntemi }\end{array}$ \\
\hline $\begin{array}{l}\text { Sunding ve } \\
\text { Swoboda } \\
(2010)\end{array}$ & $\begin{array}{l}\text { Güney } \\
\text { Kaliforniya, } \\
\text { ABD }\end{array}$ & 1993-2001 & 13.857 & $\begin{array}{l}\text { Satış Özellikleri ve } \\
\text { Fiziksel Özellikler } \\
\text { (5 değişken) }\end{array}$ & $\begin{array}{l}\text { Tam Logaritmik } \\
\text { Model, Yerel } \\
\text { Ağırlıklı } \\
\text { Regresyon (LWR) } \\
\text { Modeli }\end{array}$ & $\begin{array}{l}\text { EKK Yöntemi, } \\
\text { Parametrik } \\
\text { Olmayan Yöntem }\end{array}$ \\
\hline $\begin{array}{l}\text { Liao ve } \\
\text { Wang } \\
(2012)\end{array}$ & Changsha, Çin & $\begin{array}{l}\text { Ağustos } \\
2008 \text {-Eylül } \\
2009\end{array}$ & 46.356 & $\begin{array}{l}\text { Yapısal, Fiziksel ve } \\
\text { Mekânsal } \\
\text { Özellikler (13 } \\
\text { değişken) }\end{array}$ & $\begin{array}{l}\text { Log-Lineer } \\
\text { Model, Kantil } \\
\text { Regresyon } \\
\text { Modeli, Mekânsal } \\
\text { Gecikme Modeli }\end{array}$ & $\begin{array}{l}\text { EKK Yöntemi, } \\
\text { Mekânsal Kantil } \\
\text { Regresyon (SQR) } \\
\text { Yaklaşımı, İki } \\
\text { Aşamalı EKK } \\
\text { Yöntemi, Iki } \\
\text { Aşamalı Kantil } \\
\text { Regresyon (2SQR) } \\
\text { Yöntemi }\end{array}$ \\
\hline $\begin{array}{l}\text { Liu ve Hite } \\
\text { (2013) }\end{array}$ & Ohio, ABD & 2010 & 2.247 & $\begin{array}{l}\text { Yapısal, Mekânsal } \\
\text { ve } \\
\text { Sosyoekonomik } \\
\text { Özellikler (36 } \\
\text { değişken) }\end{array}$ & $\begin{array}{l}\text { Log-Lineer } \\
\text { Model, Mekânsal } \\
\text { Modeller, } \\
\text { Mekânsal Kantil } \\
\text { Regresyon } \\
\text { Modeli, } \\
\text { Genelleştirilmiş }\end{array}$ & $\begin{array}{l}\text { EKK Yöntemi, ỉki } \\
\text { Aşamalı EKK } \\
\text { (2SLS) Yöntemi, } \\
\text { Mekânsal İki } \\
\text { Aşamalı EKK } \\
\text { Yöntemi, } \\
\text { Mekânsal İki } \\
\text { Aşamalı Kantil } \\
\text { Regresyon (2SQR) } \\
\text { Yöntemi }\end{array}$ \\
\hline $\begin{array}{l}\text { Huang, } \\
\text { Chen, Xu ve } \\
\text { Zhou (2017) }\end{array}$ & Shangai, Çin & 2016 & 12.732 & $\begin{array}{l}\text { Yapısal, Mekânsal } \\
\text { Özellikler ve } \\
\text { Komşuluk } \\
\text { Özellikleri (11 } \\
\text { değişken) }\end{array}$ & $\begin{array}{l}\text { Log-Lineer } \\
\text { Model, Coğrafi } \\
\text { Ağırlıklı } \\
\text { Regresyon (GWR) } \\
\text { Modeli }\end{array}$ & EKK Yöntemi \\
\hline
\end{tabular}


S. G. Kangalli-Uyar - N. D. Keten

Tablo 2. Ulusal Hedonik Konut Fiyat Çalışmaları

\begin{tabular}{|c|c|c|c|c|c|c|}
\hline Çalışma & Konut Piyasası & $\begin{array}{l}\text { Örneklem } \\
\text { Dönemi }\end{array}$ & $\begin{array}{l}\text { Gözlem } \\
\text { Sayısı }\end{array}$ & $\begin{array}{l}\text { Konut } \\
\text { Özellikleri } \\
\text { ve } \\
\text { Değişken } \\
\text { Sayısı } \\
\end{array}$ & Model & Yöntem \\
\hline $\begin{array}{l}\text { ÜçDoğruk } \\
\text { (2001) }\end{array}$ & $\begin{array}{l}\text { İzmir (Konak, } \\
\text { Buca, Balçova, } \\
\text { Narlıdere, } \\
\text { Gaziemir, } \\
\text { Bornova, } \\
\text { Karşıyaka) } \\
\end{array}$ & $\begin{array}{l}\text { Mayıs, } \\
2001\end{array}$ & 2.718 & $\begin{array}{l}\text { Yapısal, } \\
\text { Fiziksel ve } \\
\text { Mekânsal } \\
\text { Özellikler } \\
\text { ( } 27 \\
\text { değişken) } \\
\end{array}$ & $\begin{array}{l}\text { Log-Lineer } \\
\text { Model }\end{array}$ & EKK Yöntemi \\
\hline $\begin{array}{l}\text { Ozus, } \\
\text { Dokmeci, } \\
\text { Kiroglu ve } \\
\text { Egdemir } \\
\text { (2007) }\end{array}$ & $\begin{array}{l}\text { İstanbul } \\
\text { (Beşiktaş, } \\
\text { Üsküdar, } \\
\text { Bakırköy, Sarıyer, } \\
\text { Maltepe, } \\
\text { Gaziosmanpaşa) }\end{array}$ & $\begin{array}{l}\text { Haziran- } \\
\text { Ağustos } \\
1997\end{array}$ & 1.468 & $\begin{array}{l}\text { Yapısal, } \\
\text { Fiziksel ve } \\
\text { Mekânsal } \\
\text { Özellikler } \\
\text { (17 } \\
\text { değişken) } \\
\end{array}$ & Lineer Model & EKK Yöntemi \\
\hline $\begin{array}{l}\text { Çağlayan ve } \\
\text { Arıkan } \\
(2011)\end{array}$ & İstanbul & $\begin{array}{l}\text { Ekim - } \\
\text { Aralık } \\
2007\end{array}$ & 992 & $\begin{array}{l}\text { Yapısal, } \\
\text { Fiziksel ve } \\
\text { Mekânsal } \\
\text { Özellikler } \\
\text { (20 } \\
\text { değişken) } \\
\end{array}$ & $\begin{array}{l}\text { Log-Lineer } \\
\text { Model, Kantil } \\
\text { Regresyon } \\
\text { Modeli }\end{array}$ & EKK yöntemi \\
\hline $\begin{array}{l}\text { Bekar } \\
(2013)\end{array}$ & İstanbul (39 ilçe) & - & 2.076 & $\begin{array}{l}\text { Yapısal, } \\
\text { Özellikler } \\
\text { (7 } \\
\text { değişken) }\end{array}$ & $\begin{array}{l}\text { Lineer Model, } \\
\text { Log-Dog Model, } \\
\text { Mekânsal } \\
\text { Modeller, } \\
\text { Mekânsal Kantil } \\
\text { Regresyon } \\
\text { Modeli }\end{array}$ & $\begin{array}{l}\text { EKK yöntemi, } \\
\text { ML Yöntemi, iki } \\
\text { Aşamalı Kantil } \\
\text { Regresyon } \\
\text { Yöntemi }\end{array}$ \\
\hline $\begin{array}{l}\text { Yayar ve Gül } \\
\text { (2014) }\end{array}$ & $\begin{array}{l}\text { Mersin Kent } \\
\text { Merkezi }\end{array}$ & $\begin{array}{l}\text { Kasım } \\
2011- \\
\text { Şubat } \\
2012\end{array}$ & 739 & $\begin{array}{l}\text { Yapısal, } \\
\text { Fiziksel ve } \\
\text { Mekânsal } \\
\text { Özellikler } \\
\text { (26 } \\
\text { değişken) } \\
\end{array}$ & $\begin{array}{l}\text { Lineer, Log- } \\
\text { Lineer, Log-Log } \\
\text { Model }\end{array}$ & EKK yöntemi \\
\hline $\begin{array}{l}\text { Kördiş, Işık } \\
\text { ve Mert } \\
\text { (2014) }\end{array}$ & $\begin{array}{l}\text { Antalya } \\
\text { (Konyaaltı, Kepez } \\
\text { ve Muratpaşa } \\
\text { IIlçeleri) }\end{array}$ & $\begin{array}{l}\text { Mart } 2013 \\
- \text { Nisan } \\
2013\end{array}$ & 2.067 & $\begin{array}{l}\text { Yapısal, } \\
\text { Fiziksel, } \\
\text { Mekânsal } \\
\text { Özellikler } \\
\text { ve } \\
\text { Komşuluk } \\
\text { Özellikleri } \\
\text { (24 } \\
\text { değişken) }\end{array}$ & $\begin{array}{l}\text { Log-Lineer } \\
\text { Model }\end{array}$ & EKK yöntemi \\
\hline $\begin{array}{l}\text { Kangallı } \\
\text { Uyar (2015) }\end{array}$ & İstanbul (39 İlçe) & $\begin{array}{l}\text { Ekim - } \\
\text { Aralık } \\
2013\end{array}$ & 2.838 & $\begin{array}{l}\text { Yapısal, } \\
\text { Fiziksel, } \\
\text { Mekânsal } \\
\text { Özellikler } \\
\text { ve } \\
\text { Komşuluk } \\
\text { Özellikleri } \\
\text { (102 } \\
\text { değişken) }\end{array}$ & $\begin{array}{l}\text { Log-Lineer } \\
\text { Model, } \\
\text { Mekânsal } \\
\text { Modeller, } \\
\text { Koşullu } \\
\text { Parametrik } \\
\text { Regresyon } \\
\text { Modeli, } \\
\text { Yarıparametrik } \\
\text { Model, LWR } \\
\text { Modeli, GWR } \\
\text { Modeli, } \\
\text { Toplamsal } \\
\text { Model }\end{array}$ & $\begin{array}{l}\text { EKK Yöntemi, } \\
\text { ML Yöntemi, } \\
\text { Yarıparametrik } \\
\text { Yöntem, } \\
\text { Parametrik } \\
\text { Olmayan } \\
\text { Yöntem }\end{array}$ \\
\hline
\end{tabular}


Tablo 2. Ulusal Hedonik Konut Fiyat Çalışmaları (Devam)

\begin{tabular}{|c|c|c|c|c|c|c|}
\hline $\begin{array}{l}\text { Daşkıran } \\
\text { (2015) }\end{array}$ & $\begin{array}{l}\text { Denizli (istiklal, } \\
\text { Servergazi ve } \\
\text { Sümer } \\
\text { Mahalleleri) }\end{array}$ & - & 102 & $\begin{array}{l}\text { Yapısal, } \\
\text { Fiziksel ve } \\
\text { Mekânsal } \\
\text { Özellikler } \\
\text { (11 } \\
\text { değişken) }\end{array}$ & Log-Log Model & EKK Yöntemi \\
\hline $\begin{array}{l}\text { Afşar, } \\
\text { Yılmazel ve } \\
\text { Yılmazel } \\
\text { (2017) }\end{array}$ & $\begin{array}{l}\text { Eskişehir } \\
\text { (Odunpazarı ve } \\
\text { Tepebaşı IIlçeleri) }\end{array}$ & $\begin{array}{l}\text { Kasım- } \\
\text { Aralık } \\
2016\end{array}$ & 4.311 & $\begin{array}{l}\text { Yapısal, } \\
\text { Fiziksel ve } \\
\text { Mekânsal } \\
\text { Özellikler } \\
\text { (40 } \\
\text { değişken) }\end{array}$ & $\begin{array}{l}\text { Log-Lineer } \\
\text { Model }\end{array}$ & EKK Yöntemi \\
\hline $\begin{array}{l}\text { Küçükkaplan } \\
\text { ve Aldı } \\
\text { (2017) }\end{array}$ & $\begin{array}{l}\text { Denizli (32 } \\
\text { mahalle) }\end{array}$ & $\begin{array}{l}2015 \text { (192 } \\
\text { iş günü) }\end{array}$ & 1.749 & $\begin{array}{l}\text { Yapısal ve } \\
\text { Fiziksel } \\
\text { Özellikler }\end{array}$ & $\begin{array}{l}\text { Panel Veri } \\
\text { Regresyon } \\
\text { Modeli }\end{array}$ & $\begin{array}{l}\text { Genelleştirilmiş } \\
\text { EKK Yöntemi }\end{array}$ \\
\hline
\end{tabular}

\section{Yöntem}

\subsection{Mekânsal Modeller}

Anselin (1988) mekânsal ekonometriyi, konumdan kaynaklanan farklııkların istatistiksel analizlere dâhil edilmesi şeklinde tanımlamaktadır. Burada mekânlar arasındaki etkileşim ile 'mekânsal etki' kavramı ortaya çıkmaktadır. Mekânsal etki, mekânsal bağımlılık ve mekânsal heterojenite olarak tanımlanmaktadır (Anselin, 1988: 15-16). Mekânsal bağımlılık, coğrafi bir konumdaki gözlem değerlerinin en yakın komşu gözlem değerleri ile ilişkili olması durumudur. Tobler (1979), coğrafyanın temel yasasını şöyle ifade etmektedir: "Herşey başka herşey ile ilişkilidir ancak yakın şeyler uzak olanlara göre daha fazla ilişki içindedir". Bu durum birbirine yakın olan birimlerin daha fazla benzerliğinin olduğunu ifade eder.

Mekânsal bağımlılık klasik doğrusal regresyon modeline iki şekilde dâhil edilmektedir. Mekânsal otoregresif bağımlı değişkenin modele bağımsız değişken olarak eklenmesi ile mekânsal otoregresif model elde edilmektedir. Başka bir deyişle, bağımlı değişkenden kaynaklanan mekânsal bağımlıık dikkate alınmaktadır. Mekânsal otoregresif model eşitlik (1)'de olduğu gibi tanımlanmıştır:

$$
Y=\rho W Y+X \beta+\varepsilon
$$

Burada $\beta$, parametre vektörü ve $\rho$, otoregresif parametredir. $\rho$, mekânsal bağımlılı̆ın derecesini gösterir ve $-1 \leq \hat{\rho} \leq 1$ 'dir. $\hat{\rho}>0$ ise mekânsal bağımlılık pozitiftir ve birbirine yakın konutların fiyatları benzerdir, yani benzer fiyatlara sahip konutların mekânsal olarak kümelenmesi söz konusudur. $\hat{\rho}<0$ ise mekânsal bağımlılık negatiftir ve birbirine yakın konutların fiyatları benzememektedir. $W, \mathrm{NxN}$ boyutundaki mekânsal ağırlık matrisidir ve bir konutun fiyatının yakınındaki konutlardan nasıl etkilendiğini tanımlar; $X$, açıklayıcı değişkenler matrisi ve $\varepsilon$, hata terimi vektörüdür.

Mekânsal otoregresif modelden farklı olarak, hata teriminden kaynaklanan mekânsal bağımlılığı dikkate almak amacı ile mekânsal hata modeli oluşturulmaktadır. Eşitlik (2) ile mekânsal hata modelinin fonksiyonel yapısı şu şekilde ifade edilmektedir:

$$
\begin{aligned}
& Y=X \beta+\varepsilon \\
& \varepsilon=\lambda W \varepsilon+u
\end{aligned}
$$

Burada $\lambda$ parametresi, hata terimleri ile komşu konumdaki hata terimleri arasında bulunan mekânsal bağımlılı̆ın seviyesini ölçmektedir. 
Mekânsal otoregresif bağımlı değişken (WY) ve mekânsal otoregresif açıklayıcı değişken (WX) içeren model Mekânsal Durbin modeli olarak ifade edilmektedir (LeSage ve Page, 2009:28). Bu model mekânsal otoregresif modelden farklı olarak, bağımlı değişkenden kaynaklanan mekânsal bağımlılığın yanı sıra açıklayıcı değişken/lerden kaynaklanan mekânsal bağımlılıkları da dikkate almaktadır. Mekânsal Durbin modeli eşitlik (4)'teki gibi tanımlanabilir:

$$
Y=\rho W Y+X \beta-\lambda W X \beta+\varepsilon, \quad \varepsilon \sim N\left(0, \sigma^{2} I\right)
$$

Ancak, mekânsal bağımlılık dâhil edilmeden önce konumlar arasındaki komşuluk ilişkilerini ifade edebilmek amacıyla mekânsal ağırlık matrisi (W) tanımlanmaktadır. Mekânsal ağırlık matrisleri sınırdaşlığa bağlı ve uzaklığa bağıı ağırlıklandırma yaklaşımı olmak üzere iki biçimde oluşturulmaktadır. Mekânsal ağılık matrisi bu yaklaşımlardan uygun olan herhangi birine göre oluşturulduktan sonra mekânsal ekonometrik model oluşturularak tahmin sonuçları elde edilmektedir. Mekânsal regresyon modellerine ilişkin tahminler Genelleştirilmiş Momentler Yöntemi (GMM), Maksimum Olabilirlik Yöntemi (ML) ve Mekânsal iki Aşamalı En Küçük Kareler (MiAEKK) yöntemleri ile yapılabilmektedir. Çalışmada mekânsal modellerin ML yöntemi ile tahmini üzerine odaklanılmıştır.

\subsubsection{Mekânsal Bağımlılık Testleri}

Mekânsal ekonometrik analizler yapılmadan önce mekânsal bağımlılı̆ı̆n varlığının incelenmesi gerekmektedir. Mekânsal bağımlılı̆ın belirlenmesinde Moran I test istatistiği ile Lagrange Çarpanı (LM) testleri kullanılabilmektedir. Moran I test istatistiği mekânsal bağımlılığın sınanmasında yaygın olarak kullanılmaktadır ancak mekânsal bağımlılı̆ın kaynağı hakkında herhangi bir bilgi vermemektedir. Bu nedenle alternatif bir test olan LM testi kullanılabilir. Moran I test istatistiğinin sıfır hipotezi reddedildiğinde LM testi kullanım için uygundur. Mekânsal bağımlıı̆ı̆ın bağımlı değişkenden kaynaklanıp kaynaklanmadığını incelemek amacı ile $L M_{\rho}\left(L M_{\text {gecikme }}\right)$ ve hata terimlerinden kaynaklanıp kaynaklandığını incelemek amacı ile $L M_{\lambda}$ $\left(L M_{\text {hata }}\right)$ istatistikleri hesaplanır. EKK kalıntılarına dayalı olarak elde edilen LM test istatistiği değerlerinin her ikisinin de anlamlı çıkması durumunda hangi mekânsal modelin kullanılacağına karar vermek için Dirençli $L M_{\rho}$ ve $L M_{\lambda}\left(R L M_{\rho}\right.$ ve $\left.R L M_{\lambda}\right)$ testleri yapılır. Bu testlerde de sıfır hipotezi reddedilirse en büyük test istatistiği kabul edilir. Eşitlik (5)'te $\lambda$ parametresine ilişkin hipotezi sınamak amacıyla $L M_{\lambda}$ test istatistiğine yer verilmiştir (Anselin, 1988; Anselin ve Rey, 1991; Florax ve De Graaff, 2004):

$$
\begin{aligned}
& H_{0}: \lambda=0 \\
& H_{a}: \lambda \neq 0 \\
& L M_{\lambda}=\left(\frac{n^{2}}{\operatorname{tr}(W \prime W+W W)}\right)\left(\frac{\hat{\varepsilon}^{\prime} W \hat{\varepsilon}}{\hat{\varepsilon}^{\prime} \hat{\varepsilon}}\right)^{2}
\end{aligned}
$$

Burada, $\mathrm{n}$ gözlem sayısını ve $\operatorname{tr}\left(W^{\prime} W+W^{2}\right)$ ifadesi ise ağılık matrisindeki kuadratik ifadenin izini göstermektedir.

$L M_{\lambda}$ test istatistiğinin anlamlı olması durumunda mekânsal hata modelinin kullanılması uygun olacaktır. Eşitlik (6)'da $\rho$ parametresine ilişkin hipotezi sınamak amacıyla $L M_{\rho}$ test istatistiğine yer verilmiştir:

$$
\begin{aligned}
& H_{0}: \rho=0 \\
& H_{a}: \rho \neq 0 \\
& L M_{\rho}=\left(\frac{n^{2}}{Q}\right)\left(\frac{\hat{\varepsilon}^{\prime} W Y}{\hat{\varepsilon}^{\prime} \hat{\varepsilon}}\right)^{2}
\end{aligned}
$$


Burada, $Q=(W X \hat{\beta})^{\prime}\left(\mathrm{I}-M_{X}\right) \frac{W X \hat{\beta})}{\hat{\sigma}^{2}}+T, M_{X}=X\left(X^{\prime} X\right) X^{\prime}, T=\operatorname{tr}\left(W^{\prime} W+W W\right)^{\prime}$ dir. $\widehat{\beta}$ ve $\widehat{\sigma}^{2}$, mekânsal otoregresif model için elde edilen maksimum olabilirlik tahmincileridir. Eşitlik (6)'da $L M_{\rho}$ test istatistiğinin anlamlı olması durumunda mekânsal otoregresif model kullanılabilmektedir. Her iki LM test istatistiği de asimptotik olarak $\chi_{(1)}^{2}$ dağılmaktadır.

$L M_{\lambda}$ ve $L M_{\rho}$ istatistiklerinin kritik değerden daha büyük olması durumunda yukarıda tanımlanan sıfır hipotezleri reddedilir. Bu durumda Dirençli $L M$ testleri $\left(R L M_{\lambda}\right.$ ve $\left.R L M_{\rho}\right)$ uygulanır ve bu testlere ait formülasyonlar eşitlik (7) ve (8)'de gösterilmektedir (Anselin ve Le Gallo, 2008):

$$
\begin{aligned}
& R L M_{\lambda}=\frac{1}{T(1-T Q)}\left(\frac{n \hat{\varepsilon}^{\prime} W \hat{\varepsilon}}{\hat{\varepsilon}^{\prime} \hat{\varepsilon}}-T Q^{-1} \cdot \frac{n \hat{\varepsilon}^{\prime} W Y}{\hat{\varepsilon}^{\prime} \hat{\varepsilon}}\right)^{2} \\
& R L M_{\rho}=\frac{1}{Q-T}\left(\frac{n \hat{\varepsilon}^{\prime} W Y}{\hat{\varepsilon}^{\prime} \hat{\varepsilon}}-T Q^{-1} \cdot \frac{n \hat{\varepsilon}^{\prime} W Y}{\hat{\varepsilon}^{\prime} \hat{\varepsilon}}\right)^{2}
\end{aligned}
$$

$R L M_{\rho}{ }^{\prime}$ nin sıfır hipotezi, $H_{0}: \rho=0, \lambda \neq 0$, hatalardaki mekânsal bağımlılığını dikkate alarak $\rho$ 'nun sıfıra eşitliğini sınar; $R L M_{\lambda}{ }^{\prime}$ ıın sıfır hipotezi, $H_{0}: \lambda=0, \rho \neq 0$, mekânsal gecikme bağımlılığını dikkate alarak $\lambda^{\prime}$ nın sıfıra eşitliğini sınar. Diğer LM testlerinde olduğu gibi RLM testlerinin asimptotik dağılımı da $\chi^{2}{ }_{(1)}$ 'e uymaktadır.

\subsection{Mekânsal Kantil Regresyon Modeli}

En küçük kareler (EKK) tahmincileri hata terimleri Normal dağıldığında, uç değerler olmadığında ve dolayısıyla sabit varyans durumunda etkinlik özelliğini korumaktadır. Ancak hata terimlerinin Normal dağılıma uymadığı ve değişen varyans durumunda EKK tahmincileri etkin olma özelliklerini yitirirler. Bu nedenle alternatif regresyon teknikleri kullanılmaktadır. Kantil regresyon (QR) yöntemi de alternatif regresyon tekniklerinden biridir ve oldukça yaygın kullanılan bir yöntemdir. QR yöntemi, veri setindeki uç değerleri dikkate aldığından ve Normal dağılım varsayımına uyma koşulu gerektirmediğinden robust bir tekniktir (Koenker ve Hallock, 2001: 144; Cade ve Noon, 2003: 412; Koenker, 2004: 74-75; McGuinness ve Bennett, 2007: 523-524). QR modeli aşağıdaki gibi gösterilebilir:

$$
Y=X \beta_{\theta}+u_{\theta}
$$

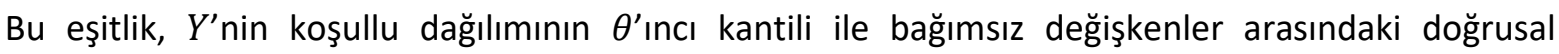
regresyonu göstermektedir. $\beta_{\theta}, \theta^{\prime}$ ncı kantil ile ilgili bilgi veren parametre vektörüdür ve $\theta \in(0,1)^{\prime}$ dir. $Y$, bağımlı değişken vektörü ve $X$, bağımsız değişkenler matrisini temsil etmektedir. Mutlak sapmaların ağırlıklandırılmış toplamları kantil regresyonun amaç fonksiyonunu vermektedir. QR'ın amaç fonksiyonu minimize edilerek $\beta_{\theta}$ parametresi elde edilir (Buchinsky, 1995):

$$
\left.\min \rho_{\theta}(y-x \beta)\right)=\rho_{\theta}(u)
$$

veya

$$
\min \left[\left(\theta\left|y-x \beta_{\theta}\right|+(1-\theta)\left|y-x \beta_{\theta}\right|\right)\right]
$$

Burada $\rho_{\theta}$ fonksiyonu, $u<0$ ise yani $y<x \beta$ olduğunda $(1-\theta) u$ ve $u \geq 0$ ise yani $y \geq x \beta$ olduğuna $\theta u$ olarak belirlenmektedir (Koenker ve Basset, 1978; Buchinsky, 1995; McGuinness ve Bennett, 2007).

QR modeline, mekânsal otoregresif terimin dâhil edilmesi ile mekânsal kantil regresyon (SQR) modeli elde edilmektedir (Liao ve Wang, 2012: 18). Mekânsal ekonometrik modellerin yeterli olmadığı bazı durumlar için farklı mekânsal yöntemlere başvurulabilir. QR'ın sabit varyans ve Normal dağıııma ilişkin varsayımlarının bulunmamasından dolayı, QR ile mekânsal ekonometrik modelin birleşmesi sonucu oluşan SQR modeli kullanılabilmektedir (Kostov, 2009: 58-60; Liao ve Wang, 2012: 18-19; Trzpiot, 2012: 270-277; Trzpiot ve 
Orwat-Acedańska, 2016: 183-184). Konut piyasası heterojen bir piyasadır ve konut piyasasına ilişkin verilerde aşırı değerler bulunabilmektedir. Bu nedenle, konut fiyatlarının dağılımının farklı dilimleri (kantilleri) için değişkenler arasındaki ilişkilerde nasıl bir değişim meydana geldiğini görebilmek SQR yaklaşımı ile mümkündür. SQR modeli eşitlik (12)'deki gibi tanımlanabilir (Trzpiot ve Acedanska; 2016):

$$
Y=\rho_{\theta} W Y+X \beta_{\theta}+\varepsilon_{\theta}
$$

Eşitlik (12)'de $\rho_{\theta}, \theta^{\prime}$ ıncı kantil için mekânsal otoregresif parametreyi; $\beta_{\theta}, \theta^{\prime}$ ıncı kantil için parametreler vektörünü ve $\varepsilon_{\theta}$, hata terimi vektörünü ifade etmektedir (Kim ve Muller 2004; Chernozhukov ve Hansen, 2006; Trzpiot ve Orwat-Acedańska, 2016).

Mekânsal kantil regresyon modeli Kim ve Muller (2004) tarafından geliştirilen iki aşamalı kantil regresyon (2SQR) yaklaşımı ile Chernozhukov ve Hansen (2006) tarafından önerilen araç değişkene dayalı kantil regresyon (IVQR) yaklaşımı kullanılabilir. Bu yaklaşımlarda mekânsal ekonometrik modellerin tahmininden ziyade bu modellerdeki $W Y$ değişkeninden kaynaklanan içsellik problemine odaklanılmaktadır. İçselliğin olması durumunda yani, hata terimleri ile bağımsız değişkenler arasında ilişki bulunduğu durumlarda tahminciler sapmalı ve tutarsız olmaktadır. Bu nedenle içsellik probleminin ortadan kaldırıması ya da bu problemin ortaya çıkmaması amacıyla 2SQR veya IVQR yaklaşımları kullanılmaktadır. IVQR yaklaşımının avantajları küçük örneklemlerde ve zayıf araç değişken durumunda bile iyi performans göstermesidir. 2SQR yaklaşımının avantajı ise mekânsal otoregresif modelin tahmininde hesapsal açıdan daha etkin olmasıdır, çünkü yöntem her bir kantil için tahminde sadece iki aşama içerir. Diğer taraftan, IVQR yaklaşımı daha fazla hesaplama gerektirir ve özellikle büyük boyutlu veri setlerinde tahminin hesapsal açıdan etkinliği daha düşüktür (Liao ve Wang, 2012: 9). Çünkü yaklaşım her bir kantil için mekânsal otoregresif katsayı üzerinden uygun ızgara değerlerinin $\left\{\rho_{\theta, m}, m=1,2, \ldots, M\right\}$ tanımlanmasını gerektirir, bu da ilgilenilen kantilde her bir Izgara değeri için $m$ tane kantil regresyonun tahmini anlamına gelir (Su ve Yang, 2011: 7-9). Bu çalışmada ise veri setinde 3666 gözlem bulunması nedeniyle, 2SQR yaklaşımı kullanılarak eşitlik (12)'deki mekânsal kantil regresyon modeli tahmin edilmiştir.

\section{Veri Seti ve Uygulama}

Denizli konut piyasasında 2019 yılı Mayıs-Haziran dönemi içerisinde satışa sunulan 3666 adet "daire" tipi konut verisi merkez ilçeler ${ }^{2}$ için derlenmiştir. Konutlara ilişkin veriler hurriyetemlak.com, sahibinden.com gibi çeşitli emlak siteleri üzerinden elde edilmiştir. Ayrıca, çalışmadaki analizler GeoDa, RStudio ve Matlab gibi çeşitli yazılımlar yardımı ile gerçekleştirilmiştir. Çalışmada birbirinden farklı konut özelliklerini kapsayan 136 tane açıklayıcı değişken belirlenmiş ve açıklayıcı değişken seçimi veri setinin büyük boyutlu olması nedeniyle Adaptive Lasso regresyon yaklaşımı ${ }^{3}$ ile yapılmıştır. Bu yaklaşıma göre çoklu doğrusal bağlılık problemine neden olan değişkenler modelden çıkarılarak konut özelliklerini kapsayan 16 değişken modele dâhil edilmiştir. Tablo 3'te çalışmada kullanılan değişkenlerin listesi ve tanımlamaları yer almaktadır. Ayrıca, Şekil 1 ve Şekil 2'de sırası ile konutların mekânsal dağııımı ile konut fiyatlarının kantillere göre dağılımı gösterilmektedir.

Tablo 3. Modelde Yer Alan Değişken İsimleri ve Değişkenlerin Tanımlamaları

\begin{tabular}{|l|l|l|}
\hline $\begin{array}{l}\text { Değişken } \\
\text { Kısaltması }\end{array}$ & Değişken Tanımı & $\begin{array}{l}\text { Değişken } \\
\text { Türü }\end{array}$ \\
\hline Ifiyat & Logaritması alınmış konut fiyatı & Nümerik \\
\hline enlem & Konutun bulunduğu konumun enlemi & Nümerik \\
\hline boylam & Konutun bulunduğu konumun boylamı & Nümerik \\
\hline m2 & Konutun alan büyüklüğü & Nümerik \\
\hline binayaşı & Konutun bulunduğu binanın yaşı & Nümerik \\
\hline banyosayısı & Konutun banyo sayısı & Nümerik \\
\hline akıllıev & Konutun akıllı ev sistemi varsa 1, yoksa 0 değerini alan kukla değişken & Kukla \\
\hline ebeveynbanyo & Konutun ebeveyn banyosu varsa 1, yoksa 0 değerini alan kukla değişken & Kukla \\
\hline
\end{tabular}


Konut Fiyatlarının Mekânsal Kantil Regresyon Yaklaşımına Göre Modellenmesi: Denizli ili Örneği

Tablo 3. Modelde Yer Alan Değişken İsimleri ve Değişkenlerin Tanımlamaları (Devam)

\begin{tabular}{|l|l|l|}
\hline gömmedolap & Konutun gömme dolabı varsa 1, yoksa 0 değerini alan kukla değişken & Kukla \\
\hline güvenlik & Konutun güvenliği varsa 1, yoksa 0 değerini alan kukla değişken & Kukla \\
\hline açık_havuz & Konutun açık yüzme havuzu varsa 1, yoksa 0 değerini alan kukla değişken & Kukla \\
\hline kapalı_havuz & $\begin{array}{l}\text { Konutun kapalı yüzme havuzu varsa 1, yoksa 0 değerini alan kukla } \\
\text { değişken }\end{array}$ & Kukla \\
\hline dHastane & Konutun en yakın hastaneye olan uzaklığı & Nümerik \\
\hline dAVM & Konutun en yakın alışveriş merkezine olan uzaklığı & Nümerik \\
\hline dBayramyeri & Konutun Bayramyeri'ne olan uzaklığı & Nümerik \\
\hline balkon & Konutun balkonu varsa 1, yoksa 0 değerini alan kukla değişken & Kukla \\
\hline otopark & Konutun otopark alanı varsa 1, yoksa 0 değerini alan kukla değişken & Kukla \\
\hline
\end{tabular}

Şekil 1. Konut Verilerinin Mekânsal Dağılımı

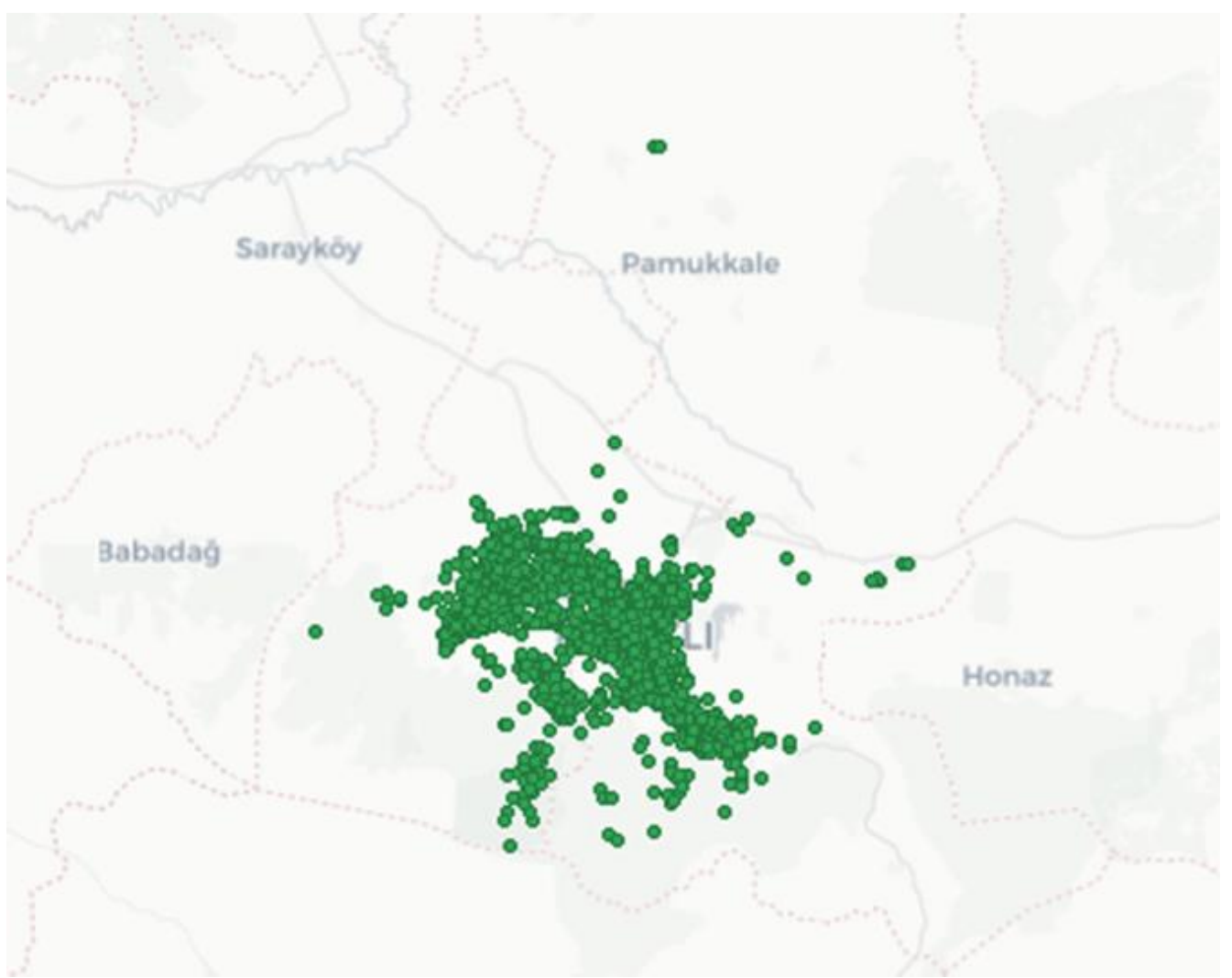


Şekil 2. Konut Fiyatlarının Kantillere Göre Dağııımı

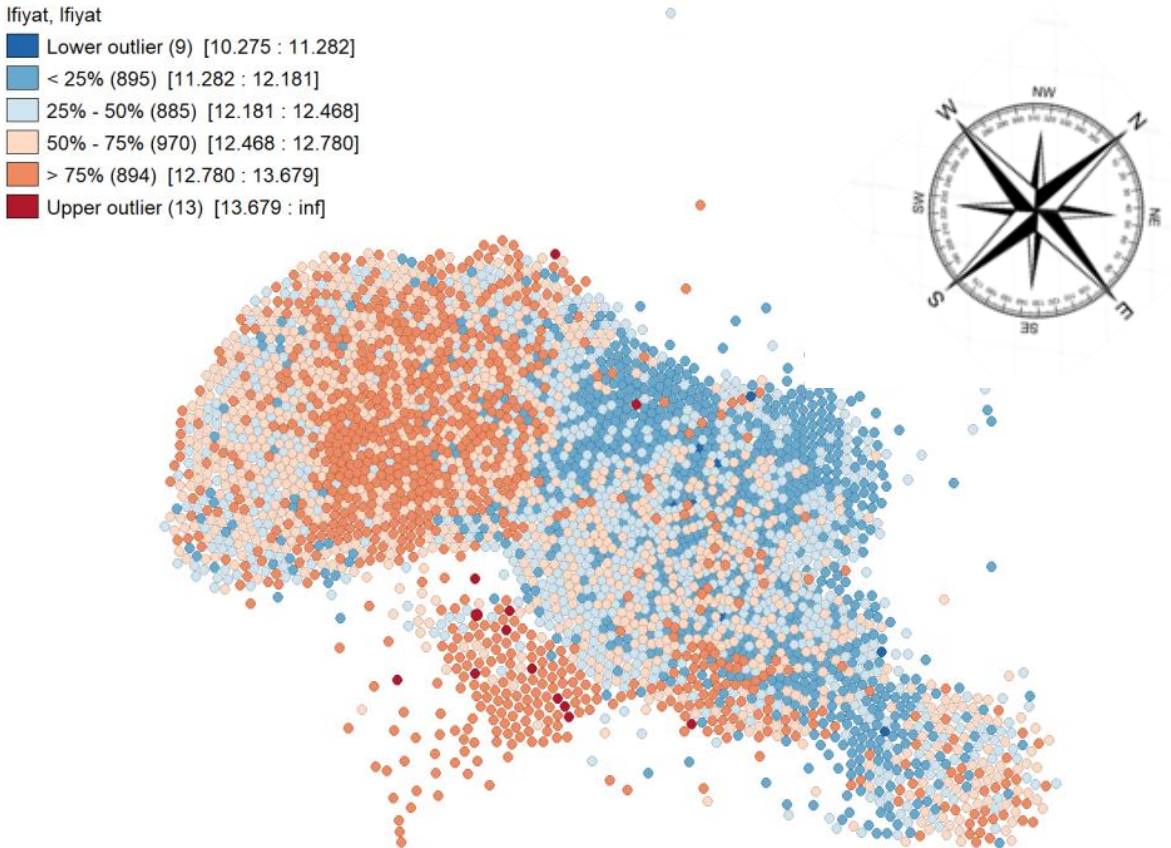

Şekil 3. Denizli ili Merkez Illçeler Haritası

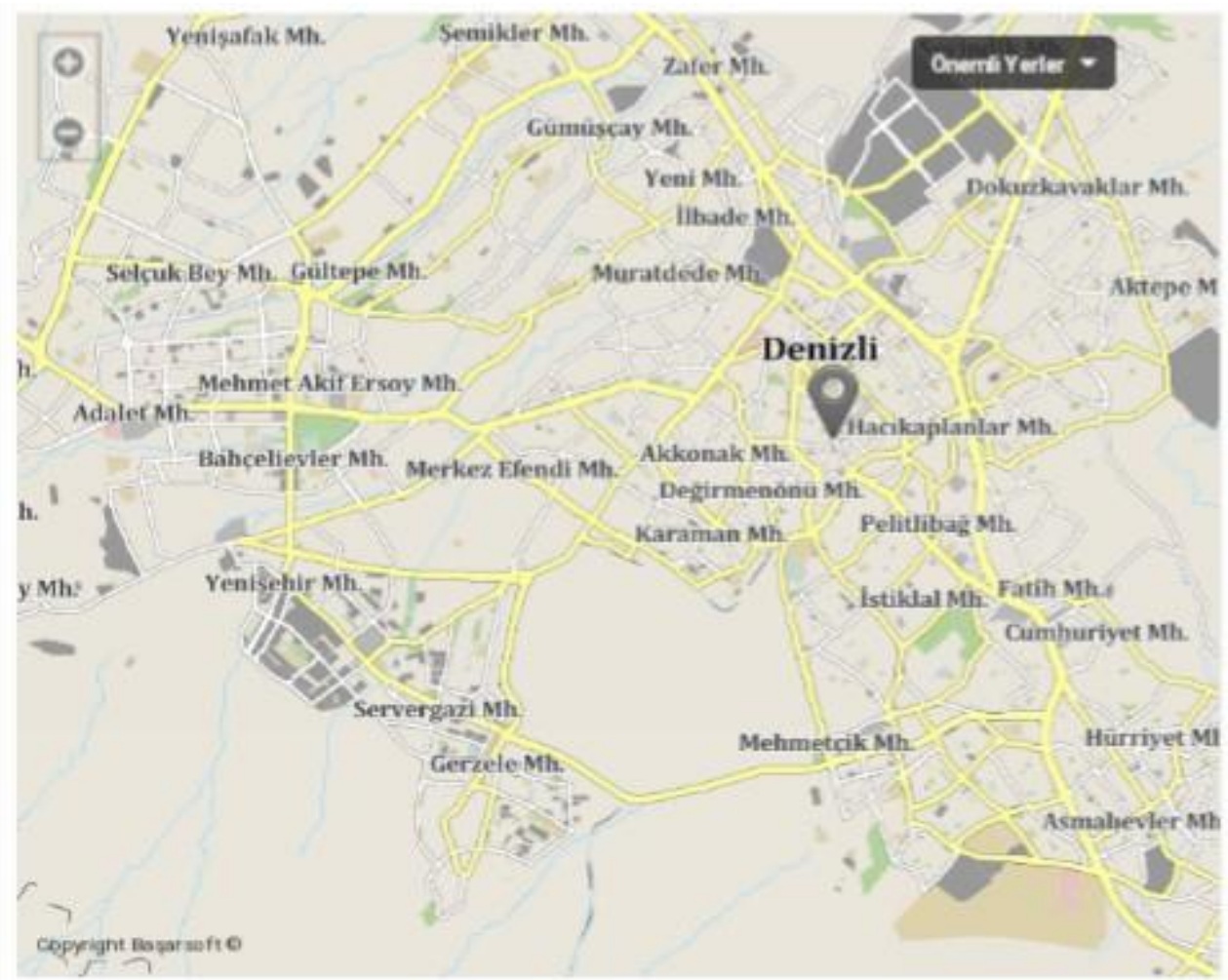

Tablo 3'te yer alan uzaklık değiş̧enleri Great Circle Distance (GCD) formülüne göre ${ }^{4}$ oluşturulmuştur. Bu formül, dünyanın şeklinin dairesel olduğunu varsaymakta ve dairesel bir yüzeyde iki nokta arasındaki uzaklığı ölçmektedir. 
Şekil 1 örnekleme dâhil edilen konutların mekânsal dağılımını ifade eder. Her bir nokta Denizli'nin merkez ilçelerine ait konutların konumunu göstermektedir. Şekil 2'de konut fiyatlarının kantillere göre dağılımı gösterilmiştir. Burada seri dört parçaya (\%25, \%50, \%75 ve \%100) bölünmüştür ve konut satış fiyatının en yüksek olduğu konumlar kırmızı, en düşük olduğu konumlar ise mavi renk ile gösterilmiştir. En yüksek \%25'lik dilimde (q75) logaritmik konut fiyatlarının 12.780-13.679 arasında değiştiği, en düşük \%25'lik dilimde (q25) ise logaritmik konut fiyatlarının 11.282-12.181 arasında değişmekte olduğu görülmektedir. Şekil 3 ve Şekil 2 birlikte incelendiğinde konut fiyatlarının mekâna göre dağılımı hakkında bilgi sahibi olunabilir. Denizli'de konut fiyatlarının en yüksek olduğu yerler; Yenişehir, Servergazi ve Gerzele mahalleleri iken konut fiyatlarının orta düzeyde olduğu yerler; Hallaçlar, 1200 Evler, Alpaslan, Kayalar, Gökpınar, Tekke, Değirmenönü, Atalar, Fesleğen, Pelitlibağ, İncilipınar, İstiklal mahalleleri olarak ortaya çıkmaktadır. Konut fiyatlarının en düşük olduğu yerler ise Aktepe, Zafer, Sümer, Fatih, Deliktaş, Topraklık, Anafartalar, Saraylar, Kayıhan, Siteler, Zeytinköy, 15 Mayıs mahalleleridir. Şekil 2'ye göre Denizli'nin kuzeyinde konut satış fiyatları en düşük değere sahip iken Denizli'nin güneyi ile batısında konut satış fiyatlarının yüksek ve orta düzeyde olduğu görülmektedir.

\subsection{Mekânsal Regresyon Modellerinin Tahminleri}

Mekânsal kantil regresyon yaklaşımı hem değişkenler arasındaki ilişkilere ait daha detaylı bilgiler sunarak hem de veri setinde varsa uç değerlerin neden olabileceği değişen varyans problemini dikkate alarak diğer mekânsal ekonometrik yaklaşımlara üstünlük sağlamaktadır. Mekânsal kantil regresyon yaklaşımının sağladığı üstünlükleri gözlemleyebilmek amacı ile klasik mekânsal ekonometrik yaklaşımla yapılan tahminlere de çalışmada yer verilmiştir. Böylece, farklı yaklaşımları karşılaştırabilme ve birinin diğerine/lerine üstünlükleri gözlemleyebilme imkânı sunulabilmektedir.

Mekânsal regresyon modellerine ilişkin tahmin sonuçları verilmeden önce k-en yakın komşu kriterine göre mekânsal ağırlık matrisi hesaplanmıştır. Konutların HFY'ye göre modellenmesinde konut verilerinin düzensiz konumlanmasından dolayı k-en yakın komşu kriteri kullanılarak mekânsal ağırlık matrisi oluşturulmuş ve Mart 2019 döneminde Denizli' de satışa sunulan 3666 adet konut verisine ilişkin örneklem ile 3666*3666 boyutunda ağırlık matrisi elde edilmiştir. Bu kritere göre her bir konuta en yakın olan k sayıda komşusu belirlenmektedir. Konutlar arasındaki uzaklıklar hesaplanırken, konutların enlem ve boylam verilerine dayanan Great Circle Distance formülü kullanılmıştır. k-en yakın komşunun belirlenmesinde çeşitli $\mathrm{k}$ değerlerine karşıık gelen mekânsal bağımlılık test istatistikleri hesaplanır. En yüksek anlamlılığa sahip test istatistiğine karşılık gelen k değeri belirlenerek ağırlık matrisi oluşturulur. Tablo 4'te çeşitli k değerlerine karşıık gelen mekânsal bağımlılık test istatistikleri değerlerine yer verilmiştir:

Tablo 4. Mekânsal Spesifikasyon Testleri

\begin{tabular}{|c|c|c|c|c|c|c|}
\hline & $k=1$ & $k=5$ & $k=10$ & $k=15$ & $k=20$ & $k=30$ \\
\hline LM_lag & $\begin{array}{c}138,57^{* * *} \\
(0,00)\end{array}$ & $\begin{array}{c}412,54 * * * \\
(0,00)\end{array}$ & $\begin{array}{c}549,17^{* * *} \\
(0,00)\end{array}$ & $\begin{array}{c}713,26 * * * \\
(0,00)\end{array}$ & $\begin{array}{c}818,68^{* * *} \\
(0,00)\end{array}$ & $\begin{array}{c}931,07^{* * *} \\
(0,00)\end{array}$ \\
\hline LM_err & $\begin{array}{c}78,609 * * * \\
(0,00)\end{array}$ & $\begin{array}{c}277,37 * * * \\
(0,00)\end{array}$ & $\begin{array}{c}621,06 * * * \\
(0,00)\end{array}$ & $\begin{array}{c}780,18^{* * *} \\
(0,00)\end{array}$ & $\begin{array}{c}1050,5^{* * *} \\
(0,00)\end{array}$ & $\begin{array}{c}1500,1^{* * *} \\
(0,00)\end{array}$ \\
\hline RLM_lag & $\begin{array}{c}59,976 * * * \\
(0,00)\end{array}$ & $\begin{array}{c}154,3^{* * *} \\
(0,00)\end{array}$ & $\begin{array}{c}195,72 * * * \\
(0,00)\end{array}$ & $\begin{array}{c}205,66 * * * \\
(0,00)\end{array}$ & $\begin{array}{c}224,2^{* * *} \\
(0,00)\end{array}$ & $\begin{array}{c}247,16^{* * *} \\
(0,00)\end{array}$ \\
\hline RLM_err & $\begin{array}{c}0,01 * * * \\
(0,00)\end{array}$ & $\begin{array}{c}19,13 * * * \\
(0,00)\end{array}$ & $\begin{array}{c}123,82 * * * \\
(0,00)\end{array}$ & $\begin{array}{c}272,58^{* * *} \\
(0,00)\end{array}$ & $\begin{array}{c}456,02 * * * \\
(0,00)\end{array}$ & $\begin{array}{c}816,22 * * * \\
(0,00)\end{array}$ \\
\hline SARMA & $\begin{array}{c}138,59 * * * \\
(0,00)\end{array}$ & $\begin{array}{c}431,67^{* * *} \\
(0,00)\end{array}$ & $\begin{array}{c}744,89 * * * \\
(0,00)\end{array}$ & $\begin{array}{c}985,84 * * * \\
(0,00)\end{array}$ & $\begin{array}{c}1274,7^{* * *} \\
(0,00)\end{array}$ & $\begin{array}{c}1747,3^{* * *} \\
(0,00)\end{array}$ \\
\hline Moran I & $\begin{array}{c}0,18^{* * *} \\
(0,00)\end{array}$ & $\begin{array}{c}1,61 * * * \\
(0,00)\end{array}$ & $\begin{array}{c}1,61^{* * *} \\
(0,00)\end{array}$ & $\begin{array}{c}1,57^{* * *} \\
(0,00)\end{array}$ & $\begin{array}{c}1,58^{* * *} \\
(0,00)\end{array}$ & $\begin{array}{c}1,55^{* * *} \\
(0,00)\end{array}$ \\
\hline
\end{tabular}

$* * *, * *, *$ sırasıyla \%1, \%5 ve \%10 anlamlılık seviyelerini göstermektedir. Parantez içindeki değerler test istatistiklerine ait olasılık değerleridir. 
Tablo 4 incelendiğinde test istatistiklerine ait değerlerin \%1 seviyesinde istatistiksel olarak anlamlı olduğu görülmektedir. Robust test istatistiklerine göre hem mekânsal otoregresif model hem de mekânsal hata modeli için optimal $k$ değeri 30 olarak alınmaktadır. Bunun temel sebebi, $k>30$ olduğunda test istatistik değerleri küçülmeye başlamaktadır. Bu nedenle optimal k değeri 30 olarak alınmıştır. Böylece, mekânsal otoregresif ve mekânsal hata modellerinin tahmininde k=30 değeri için mekânsal ağırlık matrisi oluşturulmaktadır. Şekil 5'te k-en yakın komşu kriterine göre komşuluk ilişkileri ve Şekil 6'da Moran I grafiğine yer verilmiştir.

Şekil 5. k-En Yakın Komşu Kriterine Göre Mekânsal Ağırlık Matrisi (k=30)

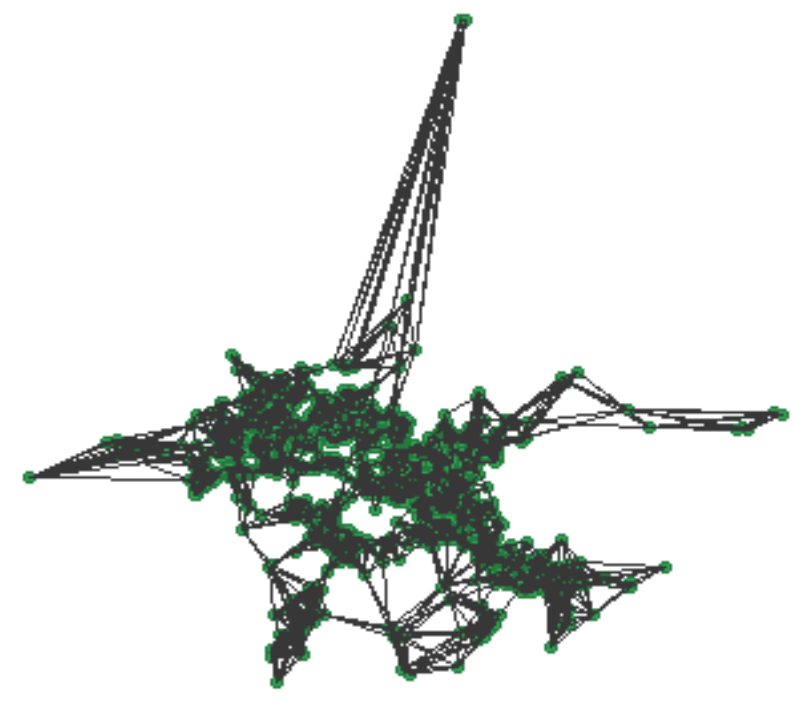

Şekil 6. Moran I Grafiği (k=30)

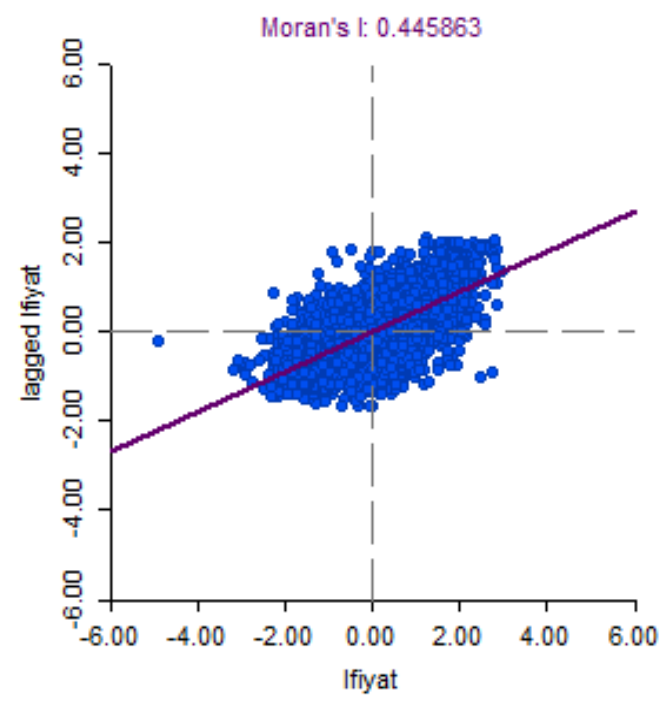

Şekil 6'daki Moran I grafiği incelendiğinde, pozitif yönde mekânsal bağımlılık bulunmaktadır. Bu sonuç, bir konumdaki konutların satış fiyatı arttıkça komşu konumdaki konutların da satış fiyatının artacağını ifade eder. Mekânsal ağırlık matrisleri oluşturulduktan sonra mekânsal regresyon modelleri tahmin edilerek tahmin sonuçları elde edilmiştir. 
Konut Fiyatlarının Mekânsal Kantil Regresyon Yaklaşımına Göre Modellenmesi: Denizli ili Örneği

Tablo 5. Mekânsal Model Tahmin Sonuçları

\begin{tabular}{|c|c|c|c|c|}
\hline Değişkenler & $\begin{array}{l}\text { EKK Modeli } \\
\text { (OLS) }\end{array}$ & $\begin{array}{c}\text { Mekânsal Otoregresif } \\
\text { Model (SAR) }\end{array}$ & $\begin{array}{l}\text { Mekânsal Hata } \\
\text { Modeli (SEM) }\end{array}$ & $\begin{array}{l}\text { Mekânsal Durbin } \\
\text { Modeli (SDM) }\end{array}$ \\
\hline \multirow[t]{2}{*}{ sabit } & $11,4718^{* * *}$ & $6,0478 * * *$ & $11,6114 * * *$ & $5,2436 * * *$ \\
\hline & $(590,541)$ & $(26,833)$ & $(360,722)$ & $(12,057)$ \\
\hline \multirow[t]{2}{*}{$\mathrm{m} 2$} & $0,0067^{* * *}$ & $0,0059 * * *$ & $0,0061 * * *$ & $0,0061 * * *$ \\
\hline & $(53,461)$ & $(49,335)$ & $(51,325)$ & $(51,191)$ \\
\hline \multirow[t]{2}{*}{ binayaşı } & $-0,0065 * * *$ & $-0,0061 * * *$ & $-0,0077 * * *$ & $-0,0076 * * *$ \\
\hline & $(-8,450)$ & $(-8,539)$ & $(-10,006)$ & $(-9,897)$ \\
\hline \multirow[t]{2}{*}{ banyosayısı } & $-0,0004$ & $-0,0099$ & $-0,0155$ & $-0,0148$ \\
\hline & $(-0,031)$ & $(-0,806)$ & $(-1,264)$ & $(-1,243)$ \\
\hline \multirow[t]{2}{*}{ akıllıev } & $0,0694 * * *$ & $0,0613^{* * *}$ & $0,0748 * * *$ & $0,0720 * * *$ \\
\hline & $(3,652)$ & $(3,477)$ & $(4,236)$ & $(4,093)$ \\
\hline \multirow[t]{2}{*}{ ebeveynbanyolu } & $0,0507^{* * *}$ & 0,0137 & $0,0220 *$ & 0,0187 \\
\hline & $(3,536)$ & $(1,0245)$ & $(1,670)$ & $(1,420)$ \\
\hline \multirow[t]{2}{*}{ gömmedolap } & 0,0036 & 0,0007 & $-0,0060$ & $-0,0024$ \\
\hline & $(0,362)$ & $(0,075)$ & $(-0,6434)$ & $(-0,266)$ \\
\hline \multirow[t]{2}{*}{ güvenlik } & 0,0194 & 0,0175 & 0,0174 & 0,0137 \\
\hline & $(1,101)$ & $(1,072)$ & $(1,075)$ & $(0,846)$ \\
\hline \multirow[t]{2}{*}{ açı__havuz } & $0,0468^{*}$ & $0,0198^{*}$ & 0,0297 & 0,0206 \\
\hline & $(2,115)$ & $(0,967)$ & $(1,4213)$ & $(0,987)$ \\
\hline \multirow[t]{2}{*}{ kapalı_havuz } & $0,0614^{*}$ & 0,0388 & $-0,0188$ & $-0,0100$ \\
\hline & $(2,119)$ & $(1,446)$ & $(-0,643)$ & $(-0,362)$ \\
\hline \multirow[t]{2}{*}{ dHastane } & $0,0245^{* * *}$ & 0,0011 & $-0,0038$ & $-0,0086$ \\
\hline & $(5,577)$ & $(0,276)$ & $(-0,340)$ & $(-0,249)$ \\
\hline \multirow[t]{2}{*}{ dAVM } & $-0,0816 * * *$ & $-0,0488 * * *$ & $-0,0926 * * *$ & $-0,0096$ \\
\hline & $(-14,610)$ & $(-9,113)$ & $(-6,303)$ & $-(0,287)$ \\
\hline \multirow[t]{2}{*}{ dBayramyeri } & $0,0643^{* * *}$ & $0,0287^{* * *}$ & $0,0787^{* * *}$ & $-0,0292$ \\
\hline & $(-17,359)$ & $(7,630)$ & $(7,010)$ & $(-0,670)$ \\
\hline \multirow[t]{2}{*}{ balkon } & $0,0455^{* * *}$ & $0,0442 * * *$ & $0,0454 * * *$ & $0,0433 * * *$ \\
\hline & $(3,928)$ & $(4,122)$ & $(4,293)$ & $(4,092)$ \\
\hline \multirow[t]{2}{*}{ otopark } & $0,0324 * *$ & 0,0061 & $0,0164 *$ & 0,0142 \\
\hline & $(3,223)$ & $(0,648)$ & $(1,741)$ & $(1,506)$ \\
\hline Log olabilirlik & $-343,237$ & $-81,646$ & $-73,007$ & $-240,237$ \\
\hline AIC & 718,47 & 197,29 & 180,01 & 190,47 \\
\hline \multirow[t]{2}{*}{ rho/lambda } & - & $0,453 * * *$ & $0,746 * * *$ & $0,529 * * *$ \\
\hline & - & {$[523,18]$} & {$[540,46]$} & {$[158,34]$} \\
\hline
\end{tabular}

***, ** ve * sırasıyla \%1, \%5 ve \%10 anlamlılık seviyelerini ifade etmektedir. Yuvarlak parantez içindeki değerler t-test istatistikleri, köşeli parantez içindeki değerler rho ve lambda katsayılarına ait LR test istatistiklerine ait değerlerdir.

Tablo 5'te yer alan mekânsal bağımlılığın modele çeşitli formlarda dâhil edildiği mekânsal modeller (SAR, SEM ve SDM) ile mekânsal etkiyi göz ardı eden EKK yaklaşımına ilişkin tahmin sonuçlarına ulaşıımıştır. Rho ve lambda katsayılarına ait LR test istatistiklerinin anlamlı olması bağımlı değişken ve hata teriminden kaynaklanan mekânsal bağımlılığın olduğunu göstermektedir. Tablo 5'te yer alan tüm modeller Akaike Bilgi Kriteri (AIC) değerleri açısından karşılaştıııldığında, en yüksek AIC değeri'nin OLS modeline ait olduğu görülmektedir. Dolayısıyla, mekânsal modellerin konut satış fiyatı ile konuta ilişkin özellikler arasındaki ilişkiyi mekânsal etkiyi dikkate almayan OLS modeline göre daha iyi açıkladığı söylenebilir. Tablo 5 'teki mekânsal modeller AIC değerlerine göre karşılaştırıldığında ise en küçük AIC değerine sahip olan modelin SEM olduğu 
görülmektedir. Bu durumda SEM, konut satış fiyatı ile konuta ilişkin özellikler arasındaki ilişkiyi açıklamada SAR ve SDM modellerine tercih edilmektedir. Çalışmada, yarı logaritmik fonksiyonel formda model kullanılması sebebi ile SEM'e ilişkin katsayılar yorumlanırken kesikli olmayan açıklayıcı değişkenlerin katsayıları 100 ile çarpılmış ve kesikli olan kukla değişkenlerin katsayıları ise Halvorsen-Palmquist (1980) yaklaşımına göre $\left(e^{\beta}-1\right) * 100$ ile çarpılarak değişkenlerin katsayı yorumlamaları yapılmıştır (Çağlayan ve Güriş, 2005).

SEM'in tahmin sonuçlarına göre kesikli olmayan açıklayıcı değişkenlerden $\mathrm{m} 2$, bina yaşı, dAVM ve dBayramyeri değişkenleri istatistiksel olarak anlamlıdır. SEM tahmin sonuçlarında kukla değiş̧enlerden ya da kesikli değişkenlerden; akıllı ev, ebeveyn banyosu, balkon ve otopark değişkenlerinin istatistiksel olarak anlamlı olduğu görülmektedir. SEM'in tahmin sonuçları konutun yapısal ve fiziksel özellikleri açısından incelendiğinde, $\mathrm{m} 2$ değişkeni konutun $\mathrm{m} 2$ başına satış fiyatını yüzde 0,61 kadar arttırmaktadır. Konutun büyüklüğü arttıkça konut satış fiyatının artıyor olmasının iktisadi beklentilere uygun olduğu söylenebilir.

Konutun bulunduğu binanın yaşı değişkeni için tahmin sonuçları, konutun bina yaşının artmasının konut satı̧ fiyatını yüzde 0,77 kadar düşürdüğünü göstermektedir. Bina yaşı fazla olan bir konutun yıpranma payının daha yüksek olması nedeniyle konut satın almak isteyen tüketiciler eski binalarda bulunan konutlar yerine yeni inşa edilen ya da edilmiş olan binalarda bulunan konutları tercih etmektedirler.

Konutun akıllı ev sisteminin olması konut satış fiyatını yüzde 7,76 oranında arttırmaktadır. Akıllı ev sistemine sahip bir konutta ışıkları açma ve kapatma, cihazları açıp kapama, klimanın ısınma ve soğutma düzeylerinin ayarlanması, ışık sensörü ile güneşin batışını algılayarak perdeleri kapatma, hareket sensörü ile alarmı tetikleme, duman sensörü ile yangını algılama gibi özelliklerin tümünün uzak bir yerden bilgisayar aracılığı ile yapılması tüketiciye oldukça cazip gelmektedir (Alga, 2005: 24-25). Tüketicinin lüks gereksinimlerini ve isteklerini karşılaması nedeniyle özellikle yüksek gelir düzeyindeki tüketiciler akıllı ev sistemine sahip konutları talep edebilmektedir.

Konutun ebeveyn banyosunun olması konut satış fiyatını yüzde 2,22 oranında arttırmaktadır. Bu durum iktisadi olarak lüks tüketim mallarına olan talep ile ifade edilebilmektedir. Konut talebinde bulunan tüketicilerin, gelir düzeylerinin ortanın üzerinde olması ve daha fazla fayda sağlamaları amacıyla lüks tüketim mallarına yönelmeleri konut satış fiyatı üzerinde artan yönde bir etkiye neden olur (Tığlı ve Akyazgan, 2003: 21-37).

Konutun balkonunun olmasının konut satış fiyatını yüzde 4,64 kadar arttırmakta olduğu görülmektedir. Korur, Sayın, Oğuzalp ve Korkmaz (2006), konut talebinde bulunan bazı tüketicilerin balkonları dağınıklığı gizleyen birer alan olarak gördüğünü, dolaplar yaptırarak da kendileri açısından kullanışlı hale getirdiklerini ifade etmektedir

Konutun otoparkının olması konut satış fiyatını yüzde 1,65 oranında arttırmaktadır. Otopark değişkeninin konut satış fiyatı üzerindeki olumlu etkisi tüketiciye ait motor, araba, bisiklet gibi araçlarının güvenliğini sağlayabileceği avantajlı bir alan olması ile açıklanabilmektedir.

Uzaklık değişkenlerinden olan konutun en yakın alışveriş merkezine olan uzaklı̆̆ı değişkeni konut satış fiyatını yüzde 9,26 oranında düşürmektedir. Konutun en yakın alışveriş merkezine olan uzaklığının artması sonucunda konut satış fiyatlarının azaldığı gözlemlenmiştir. Bu sonuç tüketicilerin alışveriş merkezlerinin (AVM) şehrin merkezi kısımlarına, ulaşım kanallarına, iş merkezlerine, okullara yakın olması nedeniyle AVM'lerin bulunduğu ya da yakın olduğu yerleşkelerde konut satın almayı tercih ettiklerinin bir göstergesidir. Ancak bu durum tüketicinin gelir düzeyine bağlı olarak değişkenlik göstermektedir.

Konutun Bayramyeri'ne olan uzaklığının artması, konut satış fiyatını yüzde 7,87 kadar arttırmaktadır. Bunun temel sebebi, Bayramyeri'nde eski iş yerlerinin, kuyumcular sokağının, döviz bürolarının, hastanelerin, bakırcılar sokağının, gündelik giyim mağazalarının, zanaat ürünlerinin, düğün alışverişlerinin yapıldığı bir konum olmasıdır. Aynı zamanda Bayramyeri'nin organize sanayiye, çevre yoluna, şehirlerarası otobüs terminaline, tren garına yakın olması, Bayramyeri'nde belediyeye ait şehir içi toplu taşıma sisteminin bir parçası olan otobüslerin başlangıç ve bitiş duraklarının bulunması ve yayaların sürekli hareket halinde olması nedeniyle Bayramyeri gürültü ve hareketliliğin fazla olduğu bir merkezdir. Elde edilen bulgu, tüketicinin gürültü ve kalabalıktan uzaklaşmak istemesinin ve bu semtin ticaret merkezi olmakla birlikte ikamet için uygun bir semt olmamasının bir sonucu olabilir. 
Veride uç değerlerin olması ve dolayısıyla değişen varyans sorununun bulunması gibi durumlarda mekânsal modeller yetersiz kalmakta ve bu aşamada uç değerlere karşı robust olan kantil regresyon yaklaşımı kullanılabilmektedir. Ayrıca kantil regresyon yaklaşımı ile bağımlı değişkenin koşullu dağılımının farklı dilimleri (kantiller) için bağımlı ile bağımsız değişkenler arasındaki ilişkilerin değişimi incelenebilir. Kantil regresyon modeline mekân etkisinin de dâhil edilmesiyle birlikte mekânsal kantil regresyon modeli elde edilmektedir. Bu nedenle çalışmada, konut satış fiyatlarında hem mekân etkisini dikkate alan hem de konut satış fiyatlarının yüksek ve düşük kantil dilimleri için konut satış fiyatı ile konut özellikleri arasındaki ilişkileri ayrı ayrı incelemeye olanak sağlayan mekânsal kantil regresyon yaklaşımı kullanılmıştır. Tablo 6'da mekânsal kantil regresyon modeline ilişkin tahmin sonuçları gösterilmiştir:

Tablo 6. Mekânsal Kantil Regresyon Modeli Tahmin Sonuçları

\begin{tabular}{|c|c|c|c|c|c|}
\hline \multicolumn{6}{|c|}{ Mekânsal Kantil Tahmin Sonuçları } \\
\hline & q10 & q25 & q50 & q75 & q90 \\
\hline \multirow[t]{2}{*}{ sabit } & $8,5716^{* * *}$ & $6,9783 * * *$ & $7,4971 * * *$ & $8,5327 * * *$ & $9,5900 * * *$ \\
\hline & $(8,626)$ & $(8,138)$ & $(13,656)$ & $(17,482)$ & $(20,990)$ \\
\hline \multirow[t]{2}{*}{$\mathrm{m} 2$} & $0,0063 * * *$ & $0,0067^{* * *}$ & $0,0070 * * *$ & $0,0072 * * *$ & $0,0073 * * *$ \\
\hline & $(33,335)$ & $(39,199)$ & $(40,262)$ & $(30,087)$ & $(29,353)$ \\
\hline \multirow[t]{2}{*}{ binayaşı } & $-0,0082 * * *$ & $-0,0094 * * *$ & $-0,0074 * * *$ & $-0,0063 * * *$ & $-0,0058 * * *$ \\
\hline & $(-7,900)$ & $(-11,835)$ & $(-8,816)$ & $(-8,456)$ & $(-4,895)$ \\
\hline \multirow[t]{2}{*}{ banyosayısı } & 0,0146 & 0,0029 & $0,0409 * * *$ & $0,0511^{* * *}$ & $0,0911^{* * *}$ \\
\hline & $(0,710)$ & $(0,155)$ & $(2,858)$ & $(3,566)$ & $(3,610)$ \\
\hline \multirow[t]{2}{*}{ akıllıev } & $0,1007^{* * *}$ & $0,1012 * * *$ & $0,1024 * * *$ & $0,1035^{* * *}$ & $0,0857 * * *$ \\
\hline & $(3,883)$ & $(4,735)$ & $(4,430)$ & $(5,242)$ & $(2,748)$ \\
\hline \multirow[t]{2}{*}{ ebeveynbanyolu } & $0,0899 * * *$ & $0,0278 *$ & 0,0024 & 0,0123 & 0,0004 \\
\hline & $(4,190)$ & $(1,660)$ & $(0,141)$ & $(0,759)$ & $(0,0174)$ \\
\hline \multirow[t]{2}{*}{ gömmedolap } & $-0,0032$ & 0,0061 & 0,0022 & 0,0098 & 0,0048 \\
\hline & $(-0,223)$ & $(0,610)$ & $(0,230)$ & $(0,898)$ & $(0,418)$ \\
\hline \multirow[t]{2}{*}{ güvenlik } & 0,0004 & 0,0137 & 0,0139 & 0,0292 & 0,0469 \\
\hline & $(0,015)$ & $(0,686)$ & $(0,898)$ & $(1,281)$ & $(1,378)$ \\
\hline \multirow[t]{2}{*}{ açık_havuz } & $0,1020 * * *$ & $0,0628 * * *$ & $0,0695 * * *$ & $0,0988 * * *$ & $0,1154^{* *}$ \\
\hline & $(3,054)$ & $(2,908)$ & $(2,853)$ & $(4,444)$ & $(2,556)$ \\
\hline \multirow[t]{2}{*}{ kapalı_havuz } & $-0,0117$ & 0,0140 & 0,0056 & $0,1104^{*}$ & $0,3339 * * *$ \\
\hline & $(-0,203)$ & $(0,489)$ & $(0,141)$ & $(1,768)$ & $(3,647)$ \\
\hline \multirow[t]{2}{*}{ dHastane } & 0,0119 & 0,0055 & $0,0078 *$ & 0,0076 & $0,0277 * * *$ \\
\hline & $(1,293)$ & $(0,874)$ & $(1,692)$ & $(1,325)$ & $(3,830)$ \\
\hline \multirow[t]{2}{*}{ dAVM } & $-0,0434 * * *$ & $-0,0337 * * *$ & $-0,0501 * * *$ & $-0,0635 * * *$ & $-0,0968 * * *$ \\
\hline & $(-4,016)$ & $(-3,873)$ & $(-6,033)$ & $(-10,496)$ & $(-10,070)$ \\
\hline \multirow[t]{2}{*}{ dBayramyeri } & $0,0308^{* * *}$ & $0,0234 * * *$ & $0,0348 * * *$ & $0,0390 * * *$ & $0,0521 * * *$ \\
\hline & $(4,572)$ & $(3,226)$ & $(6,686)$ & $(7,423)$ & $(7,954)$ \\
\hline \multirow[t]{2}{*}{ balkon } & $0,0704^{* * *}$ & $0,0500 * * *$ & $0,0398 * * *$ & 0,0129 & 0,0228 \\
\hline & $(4,699)$ & $(4,635)$ & $(3,490)$ & $(1,173)$ & $(1,304)$ \\
\hline \multirow[t]{2}{*}{ otopark } & 0,0096 & $-0,0060$ & $-0,0023$ & $-0,0064$ & $-0,0080$ \\
\hline & $(0,727)$ & $(-0,616)$ & $(-0,217)$ & $(-0,647)$ & $(-0,558)$ \\
\hline \multirow[t]{2}{*}{ wy } & $0,2214 * * *$ & $0,3581 * * *$ & $0,3198 * * *$ & $0,2464 * * *$ & $0,1654^{* * *}$ \\
\hline & $(3,336)$ & $(5,288)$ & $(7,836)$ & $(5,811)$ & $(4,425)$ \\
\hline
\end{tabular}

$* * *, * *, *$ sırasıyla $\% 1, \% 5$ ve $\% 10$ anlamlılık seviyelerini ifade etmektedir. Parantez içindeki değerler bootstrap Z-test istatistiklerini ifade etmektedir. 
Mekânsal kantil regresyon modelinin tahmin sonuçları, konut fiyatlarının verili konut özelliklerine koşullu dağıımının farklı dilimleri için konut fiyatları ve özellikleri arasındaki ilişkileri göstermektedir. Konut fiyatlarının koşullu dağılımının farklı dilimleri çalışmada q10, q25, q50, q75 ve q90 olarak belirlenmiştir. "q10", konut fiyatlarının en düşük olduğu \%10'luk dilimi; "q25", konut fiyatlarının en düşük olduğu \%25'lik dilimi; "q50", konut fiyatlarının \%50'lik dilimini; "q75", konut fiyatlarının en yüksek olduğu \%25'lik dilimi ve "q90", konut fiyatlarının en yüksek olduğu \%10'luk dilimi göstermektedir. Tablo 6 'daki tahmin sonuçlarına göre konut özelliklerinin konut fiyatları üzerindeki etkileri farklı dilimlere göre değişkenlik göstermektedir. Konut fiyatlarının yüksek olduğu dilimdeki konutların yüksek gelir düzeyindeki tüketiciler; konut fiyatlarının düşük olduğu dilimdeki konutların ise düşük gelir düzeyindeki tüketiciler tarafından talep edilme olasılığı daha yüksektir. Bu nedenle, çalışmanın bulguları yorumlanırken konut özelliklerinin yüksek ve düşük fiyatlı konutlar üzerindeki etkilerinin farklılaşması tüketicilerin gelir düzeyleri ile ilişkilendirilmiştir.

Tahmin sonuçları incelendiğinde konut satış fiyatını negatif yönde etkileyen değişkenler binayaşı ve $d A V M$ değişkenleridir. Kantillere göre konut özelliklerinin konut satış fiyatı üzerindeki etki büyüklükleri incelendiğinde konut satış fiyatını en fazla negatif yönde etkileyen değişken $d A V M$ değişkenidir. q10 için en yakın alışveriş merkezine uzaklık konut satış fiyatını \%4,34 oranında, q90 için \%9,68 oranında düşürmektedir. q25 için en yakın alışveriş merkezine uzaklık konut satış fiyatını \%3,37 oranında, q75 için \%6,35 oranında düşürmektedir. Buna göre, konut fiyatlarının en yüksek olduğu \%10 luk ve \%25'lik dilimlerde (q90 ve q75), en düşük olduğu \%10'luk ve \%25'lik dilimlere göre (q10 ve q25) en yakın alışveriş merkezine uzaklık arttıkça konut satış fiyatları daha fazla düşmektedir. Denizli ilinde yer alan alışveriş merkezleri konut satış fiyatlarının yüksek olduğu konumlarda bulunmakta dolayısıyla yüksek gelir düzeyindeki tüketicilerin konut talepleri alışveriş merkezlerinin çevresinde yoğunlaşmaktadır. Ayrıca Denizli'de alışveriş merkezlerine yakın konumların tercih edilmesinin başka bir sebebi de Bayramyeri merkezinin aksine ticari faaliyetlerin bir çatı altında toplanması ile gürültü ve kalabalık etmeninin sadece bir yöne çekilmesi, tüketicinin istediği zaman alışveriş, kültür, sanat, eğlence, spor faaliyetlerini gerçekleştirebilmesidir. Bu alanlar konut satış fiyatını arttırmakta ve yüksek gelir düzeyindeki tüketiciler tarafından daha çok tercih edilmektedir.

Konutun bulunduğu bina yaşının artması q10 için konut satış fiyatını \%0,82 oranında ve q90 için \%0,58 oranında negatif yönde etkilemektedir. q25 için bina yaşı arttıkça konut satış fiyatı \%0,94 ve q75 için \%0,63 oranında düşmektedir. Satış fiyatları açısından en yüksek \%10'luk ve \%25'lik dilimdeki konutlar için yıpranma payının artması, en düşük $\% 10^{\prime} l u k$ ve $\% 25^{\prime}$ lik dilimdeki konutlara göre satış fiyatlarını daha az oranda düşürmektedir.

Konut alanının büyüklüğündeki ( $\mathrm{m} 2$ değişkeni) artış q90 için konut satış fiyatını \%0,73 oranında, q10 için konut satış fiyatını \%0,63 oranında arttırmaktadır. q75 için konut satış fiyatını \%0,72 oranında, q25 için konut satış fiyatını \%0,67 oranında arttırmaktadır. Buna göre, satış fiyatları açısından en yüksek \%10'luk ve \%25'lik dilimlerde olan konutların m2'si arttıkça konut satış fiyatları diğer dilimlerdeki konutlarınkine göre daha fazla artacaktır.

Banyo sayısındaki artış konut satış fiyatını q50, q75 ve q90 için sırasıyla \%4,09, \%5,11 ve \%9,11 oranında artıırmaktadır. Buna göre, konut satış fiyatlarının en yüksek olduğu \%10'luk dilimde banyo sayısındaki artış konut satış fiyatlarını diğer kantil dilimlerine göre daha fazla arttırmaktadır.

Konutun akıllı ev sisteminin olması, q75 için konut satış fiyatını diğer kantil dilimlerine göre \%10,90 $\left(=\left(e^{0.1035}-1\right) * 100\right)^{1}$ ile daha fazla arttırmaktadır, ancak q90 için artış oranı diğer kantillere göre daha düşüktür. Bu bulgu, akıllı ev sistemine sahip konutun tüketici için konfor sağlaması ve yüksek gelir düzeyine sahip tüketiciler tarafından tercih edilmesi sonucu konut satış fiyatının artması ile açıklanabilir.

Konutun ebeveyn banyosunun olması q10 için konut satış fiyatını \%9,40 oranında ve q25 için \%2,81 oranında arttırmaktadır. Ebeveyn banyosu değişkenine ilişkin katsayı tahminleri diğer kantil dilimleri için

\footnotetext{
1 Kesikli değişkenlere ilişkin katsayı değerleri, modelin formunun yarı-logaritmik olması nedeniyle, $\left(e^{\hat{\beta}}-1\right)^{*} 100$ formülü ile hesaplanarak yorumlanmıştır. Bu nedenle, bulguların yorumunda Tablo 7'de yer alan katsayı tahmin değerlerinden farklı değerler yer almaktadır.
} 
istatistiksel olarak anlamsız çıkmıştır. Bu sonuç konut satış fiyatlarının en yüksek olduğu dilimlerdeki konutlar için ebeveyn banyosunun lüks konut özelliği olarak algılanmaması ile ilgili olabilir.

Konutun açık yüzme havuzunun olması tüm kantillerde konut satış fiyatını arttırmaktadır, ancak en fazla q90 için \%12,23 ile konut satış fiyatını arttırmaktadır. Konutun kapalı yüzme havuzunun olması ise sadece konut satış fiyatlarının en yüksek olduğu \%10'luk ve \%25'lik dilimler için konut satış fiyatını sırasıyla $\% 39,63$ ve \%11,67 oranında arttırmaktadır. Bu bulgular açık ve kapalı yüzme havuzlarının konut talep edenler tarafından lüks konut özelliği olarak algılandığının bir göstergesi olabilir.

Konutun balkonunun olması konut satış fiyatlarını q10, q50 ve q25'inci kantillerde arttırmaktadır. Ancak, konut satış fiyatlarının en yüksek olduğu kantil dilimleri için (q75 ve q90) balkon değişkenin katsayı tahminleri anlamlı değildir. Bu sonuç, özellikle düşük ve orta gelir düzeyinde olup konut talep eden tüketicilerin kendine ait bir alan gereksiniminde bulunması ve de gerek depolama gerekse de kişisel aktivitelerini gerçekleştirebilecekleri birer hobi alanı olarak balkonu olan konutları tercih etmeleri şeklinde açıklanabilmektedir.

Denizli'nin ticaret merkezi olan Bayramyeri'ne uzaklığın (dBayramyeri) artması konut satış fiyatlarını en fazla q90 için \%5,21 oranında arttırmaktadır. Bayramyeri'nden uzaklaştıkça konut satış fiyatlarının artması, Bayramyeri'nin sürekli hareket halinde olan merkezi bir yapıya sahip olması ve Bayramyeri'nde daha çok eski yapıdaki konutların bulunması nedeniyle yüksek gelir düzeyindeki tüketicilerin, düşük olanlara göre, Bayramyeri'ne uzak konumdaki konutları daha fazla tercih etmeleri etkili olmuş olabilir.

En yakın hastaneye olan uzaklık (dHastane) arttıkça konut satış fiyatları en fazla \%2,77 ile q90 için artmaktadır. q50 için konut satış fiyatları \%0,78 oranında artmaktadır, ancak diğer kantil dilimleri için dHastane değişkenine ilişkin katsayı tahminleri anlamlı değildir. Buna göre, hastaneden uzaklaştıkça konut satış fiyatlarının artması, özellikle yüksek gelir düzeyine sahip tüketicilerin gürültü, kalabalık, çevre kirliliği, trafik gibi etmenler nedeniyle hastane yakınlarında bulunan konutları talep etmemesi ile açıklanabilir.

Wy değişkeni için kantillere göre katsayı tahminleri incelendiğinde, tüm kantiller için mekânsal otoregresif katsayının istatistiksel olarak anlamlı olduğu söylenebilir. $W y^{\prime} y e$ ait katsayı büyklükleri kantil dilimlerine göre farklıık göstermekle birlikte pozitif işaretlidir. Bu sonuç, komşu konumlarda bulunan konut fiyatlarındaki artışın konut satış fiyatını arttırdığını göstermektedir. Komşu konumlarda bulunan konut satış fiyatlarındaki artış en fazla \%35,81 ile q25'inci dilimde konut satış fiyatını artırmaktadır.

\section{Sonuç}

Denizli konut piyasasının incelendiği bu çalışmada konut satış fiyatı ve konut özellikleri arasındaki ilişkiler hedonik fiyat teorisi çerçevesinde mekân etkilerinin de dikkate alındığı çeşitli mekânsal modeller ile incelenmiştir. Tahmin sonuçları arasında konut fiyatlama modellerinde mekân etkisini gözardı etmenin sonuçlarını göstermek amacı ile konut satış fiyatlarının tüm mekânlar için aynı olduğunu varsayan en küçük kareler yöntemine dayalı model tahmin sonuçlarına da yer verilmiştir. Konut satış fiyatlarında mekân etkisini çeşitli formlarda dikkate alan standart mekânsal ekonometrik modellerden mekânsal hata modeli, bazı kriterlere göre konut satış fiyatları ile konut özellikleri arasındaki ilişkiyi en iyi açıklayan model olarak belirlenmiştir. Daha sonra, konut satış fiyat verilerindeki uç değerlere ve dolayısıyla ekonometrik modelde karşılaşılabilecek değişen varyans problemine karşı dirençli olan mekânsal kantil regresyon yaklaşımı ile ilişkiler incelenmiştir. Bu yaklaşım, mekân etkisi ile birlikte veri setindeki uç değerlerin neden olacağı değişen varyans problemini dikkate almakla birlikte konut satış fiyatlarının koşullu dağılımının farklı dilimleri için konut satış fiyatları ile konut özelliklerinin incelenmesine izin vermektedir. Konut satış fiyatlarının en yüksek ve en düşük olduğu dilimler için konut özelliklerinin satış fiyatlarını aynı düzeyde etkilediğini varsaymak gerçekçi bir varsayım değildir. Bu açıdan, konutların satış fiyatları ile özellikleri arasındaki ilişkinin tüm resmini ortaya koymada mekânsal kantil regresyon yaklaşımının diğer mekânsal modellere göre avantaj sağladığı söylenebilir.

Mekânsal kantil regresyon modeline ait bulgular değerlendirildiğinde Denizli'nin merkez ilçelerinde konut satış fiyatını etkileyen değişkenler Bayramyeri'ne uzaklık, en yakın alışveriş merkezine uzaklık, en yakın 
hastaneye uzaklık; konutun fiziksel özellikleri olarak tanımlanabilen $\mathrm{m} 2$, banyo sayısı, akıllı ev sistemi, ebeveyn banyosu ve konutun yapısal özellikleri altında açık yüzme havuzu, kapalı yüzme havuzu, balkon ve bina yaşı değişkenleri olarak belirlenmiştir. Buna göre, konut fiyatlarını etkileyen fiziksel ve yapısal konut özelliklerinin genel olarak lüks konut özellikleri olduğu gözlemlenmektedir. Daşkıran (2015), Denizli konut piyasası için konut fiyatlarını pozitif yönde etkileyen konut özelliklerinin genellikle lüks konut özellikleri olduğu bulgusuna ulaşmıştır. Küçükkaplan ve Aldı (2017), Denizli konut piyasası için konut fiyatlarını etkileyen en önemli değişkenin konutun bulunduğu konum olduğu sonucuna ulaşmıştır. Bu çalışmada hem lüks sayılabilecek yapısal ve fiziksel konut özellikleri hem de mekânsal konut özellikleri olarak ifade edilen uzaklık değişkenleri konut fiyatlarını etkileyen önemli değişkenler olarak belirlenmiştir. Bu değişkenlerin konut satış fiyatları üzerindeki etkileri farklı kantil dilimlerine göre değişmektedir. Çalışmada, konut fiyatları açısından en yüksek dilimde yer alan konutları talep edebilecek tüketicilerin yüksek gelir düzeyine sahip olduğu ve düşük gelir düzeyindeki tüketicilerin konut fiyatları açısından en düşük dilimde yer alan konutları talep edebilecekleri ilişkisi kurulmuş ve tahmin sonuçları bu doğrultuda yorumlanmıştır. Konutlarda ebeveyn banyosu ve balkonun bulunması en yüksek dilimdeki konutların fiyatlarını etkilememektedir, bu da konut talep eden yüksek gelir düzeyine sahip tüketiciler için bu özelliklerin lüks konut özelliği olarak algılanmadığının bir göstergesidir. Kapalı yüzme havuzu ise en yüksek dilimdeki konutların fiyatlarını önemli ölçüde arttıran konut özelliklerinden biridir. En yüksek dilimdeki konutların fiyatları alışveriş merkezine uzaklık arttıkça diğer dilimlere göre daha fazla düşmektedir. Diğer taraftan, hastane ve Bayramyeri'ne uzaklık arttıkça diğer dilimlere göre en yüksek dilimdeki konutların fiyatları daha fazla artmaktadır. Buna göre, yüksek gelir seviyesine sahip tüketiciler alışveriş merkezlerine yakın, ancak hastane ve Bayramyeri semtinden uzak mekânlarda konut talep etmektedir. Bina yaşındaki artış ise konutların fiyatlarının en düşük olduğu dilimdeki konutların fiyatlarını diğer dilimlere göre daha fazla düşürmektedir. Bu sonuç, binadaki yıpranma payının düşük fiyatlı konutları daha fazla etkilediğinin ve bu konutları talep eden tüketiciler için de bina yaşının önemli bir faktör olduğunun göstergesi olabilir.

Çalışmanın en dikkat çekici bulgularından biri de mekânsal otoregresif değişkenin (Wy) tüm kantillerde istatistiksel olarak anlamlı olması ile birlikte konut satış fiyatları üzerindeki etki büyüklüklerinin de kantile göre farklııık göstermesidir. Buna göre, komşu konutların fiyatlarındaki artış en fazla konut fiyatlarının en düşük olduğu \%25'lik dilim için konut fiyatlarını arttırmaktadır.

Denizli konut piyasasının incelendiği bu çalışmada, konut satış fiyatlarını etkileyen özellikler belirlenmiş ve konut satış fiyatları dağıımının farklı dilimleri için konut satış fiyatları ve konut özellikleri arasındaki ilişkilerin değişimi incelenmiştir. Bulgulardan hareketle, dolaylı olarak, Denizli Piyasası'nda konut talep eden tüketicilerin tercihlerine ilişkin bilgilere ulaşıımıştır. Konut satış fiyatlarının en yüksek ve en düşük olduğu dilimler için konut satış fiyatlarını en çok arttıran ve en çok düşüren özelliklerin belirlenmesi konut talebinde bulunan farklı gelir düzeyine sahip hanehalklarının konut tercihleri hakkında bilgi sağlar. Böylece, yatırımcılar farklı hanehalkı gruplarının konut taleplerine uygun olarak konut projelerini gerçekleştirebilir.

\section{Beyan ve Açıklamalar (Disclosure Statements)}

1. Bu çalışmanın yazarları, araştırma ve yayın etiği ilkelerine uyduklarını kabul etmektedirler (The authors of this article confirm that their work complies with the principles of research and publication ethics).

2. Yazarlar tarafından herhangi bir çıkar çatışması beyan edilmemiştir (No potential conflict of interest was reported by the authors).

3. Bu çalışma, intihal tarama programı kullanılarak intihal taramasından geçirilmiştir (This article was screened for potential plagiarism using a plagiarism screening program). 


\section{Son Notlar}

1. Bu çalışma, 2019 yılında Pamukkale Üniversitesi Sosyal Bilimler Enstitüsünde Sinem Güler Kangallı Uyar'ın danışmanlığında hazırlanan Nur Duygu Keten'in yüksek lisans tezine dayanmaktadır.

2. Denizli'nin 19 ilçesi olmakla birlikte merkez ilçeleri Merkezefendi ve Pamukkale ilçeleridir. Merkezefendi (39) ve Pamukkale (30) ilçelerindeki 69 mahalleye ilişkin konut verileri toplanmıştır.

3. Adaptive Lasso regresyon yaklaşımının detaylı incelemesi için Zou (2006) ve Ogutu, Schulz-Streeck ve Piepho (2012) çalışmaları incelenebilir.

4. GCD'nin hesaplanabilmesi için gerekli formül $\Delta(\hat{\sigma})=2 \arcsin \left(\sqrt{\sin ^{2}\left(\frac{\Delta \emptyset}{2}\right)+\cos \emptyset_{s} \cos \emptyset_{f} \sin ^{2}\left(\frac{\Delta \lambda}{2}\right)}\right)$ şeklinde ifade edilebilir. Burada, $\emptyset$ enlem ve $\lambda$ boylamdır.

5. Kesikli değişkenlere ilişkin katsayı değerleri, modelin formunun yarı-logaritmik olması nedeniyle, $\left(e^{\hat{\beta}}-1\right)^{*} 100$ formülü ile hesaplanarak yorumlanmıştır. Bu nedenle, bulguların yorumunda Tablo 7'de yer alan katsayı tahmin değerlerinden farklı değerler yer almaktadır.

\section{Kaynaklar}

Afşar, A., Yılmazel, Ö., \& Yılmazel, S. (2017). Konut fiyatlarını etkileyen faktörlerin hedonik model ile belirlenmesi: Eskişehir örneği. Selçuk Üniversitesi Sosyal Bilimler Enstitüsü Dergisi, (37), 195-205.

Alga, R. (2005). Yaşam döngüsüne bağı olarak konut tasarımını etkileyen faktörler. İstanbul Teknik Üniversitesi Fen Bilimleri Enstitüsü, Yayımlanmamış Yüksek Lisans Tezi, İstanbul.

Anglin, P. M., \& Gencay, R. (1996). Semiparametric estimation of a hedonic price function. Journal of Applied Econometrics, 11(6), 633-648.

Anselin, L. (1988). Spatial econometrics: Methods and models. Netherlands: Kluwer Academic Publishers.

Anselin, L., \& Le Gallo, J. (2006). Interpolation of air quality measures in hedonic house price models: Spatial aspects. Spatial Economic Analysis, 1(1), 31-52.

Anselin, L., \& Lozano-Gracia, N. (2008). Errors in variables and spatial effects in hedonic house price models of ambient air quality. Empirical Economics, 34(1), 5-34.

Anselin, L., \& Rey, S. (1991). Properties of tests for spatial dependence in linear regression models. Geographical Analysis, 23(2), 112-131.

Basu, S., \& Thibodeau, T. G. (1998). Analysis of spatial autocorrelation in house prices. The Journal of Real Estate Finance and Economics, 17(1), 61-85.

Bekar, E. (2013). Hedonik konut fiyatlarının mekânsal kantil regresyon modeli ile analizi. Marmara Üniversitesi Sosyal Bilimler Enstitüsü, Yayımlanmamış Yüksek Lisans Tezi, İstanbul.

Bourassa, S. C., Cantoni, E., \& Hoesli, M. (2007). Spatial dependence, housing submarkets, and house price prediction. The Journal of Real Estate Finance and Economics, 35(2), 143-160.

Buchinsky, M. (1995). Estimating the asymptotic covariance matrix for quantile regression models a Monte Carlo study. Journal of Econometrics, 68(2), 303-338.

Cade, B. S., \& Noon, B. R. (2003). A gentle introduction to quantile regression for ecologists. Frontiers in Ecology and the Environment, 1(8), 412-420.

Chernozhukov, V., \& Hansen, C. (2006). Instrumental quantile regression inference for structural and treatment effect models. Journal of Econometrics, 132(2), 491-525.

Çağlayan, E., \& Arıkan, E. (2011). Determinants of house prices in Istanbul: A quantile regression approach. Quality \& Quantity, 45(2), 305-317.

Çağlayan, E. ve Güriş, B. (2005). Yarı logaritmik modellerde kukla değişkenlerin katsayılarının yorumu. Marmara Üniversitesi i.i.B.F. Dergisi, 20(1), 393-401.

Daşkıran, F. (2015). Denizli kentinde konut talebine etki eden faktörlerin hedonik fiyatlandırma modeli ile tahmin edilmesi. Uluslararası Sosyal Araştırmalar Dergisi, 8(37), 850-857.

Farber, S., \& Yeates, M. (2006). A comparison of localized regression models in a hedonic house price context. Canadian Journal of Regional Science, 29(3), 405-420.

Martins-Filho, C., \& Bin, O. (2005). Estimation of hedonic price functions via additive nonparametric regression. Empirical Economics, 30(1), 93-114. 
Fletcher, M., Gallimore, P., \& Mangan, J. (2000). Heteroscedasticity in hedonic house price models. Journal of Property Research, 17(2), 93-108.

Florax, R. J., \& De Graaff, T. (2004). The performance of diagnostic tests for spatial dependence in linear regression models: A meta-analysis of simulation studies. EditorsL. Anselin, R.J.G.M. Florax, S.J. Rey (Ed.), Advances in Spatial Econometrics içinde (29-65 ss.). Berlin; Heidelberg: Springer.

Halvorsen, R., \& Palmquist, R. (1980). The interpretation of dummy variables in semi-logarithmic equations. American Economic Review, 70(3), 474-475.

Haurin, D. R., \& Brasington, D. (1996). School quality and real house prices: Inter-and intrametropolitan effects. Journal of Housing Economics, 5(4), 351-368.

Huang, Z., Chen, R., Xu, D., \& Zhou, W. (2017). Spatial and hedonic analysis of housing prices in Shanghai. Habitat International, 67, 69-78.

Kangallı Uyar, S.G. (2015). Hedonik fiyat teorisi çerçevesinde istanbul konut piyasası fiyat dinamiklerinin parametrik ve parametrik olmayan mekânsal modeller ile karşılaştırmalı analizi. Pamukkale Üniversitesi Sosyal Bilimler Enstitüsü, Yayımlanmamış Doktora Tezi, Denizli.

Kestens, Y., Thériault, M., \& Des Rosiers, F. (2006). Heterogeneity in hedonic modelling of house prices: Looking at buyers' household profiles. Journal of Geographical Systems, 8(1), 61-96.

Kim, T. H., \& Muller, C. (2000). Two-stage quantile regression. Discussion Papers in Economics No. 00/1.

Kim, T. H., \& Muller, C. (2004). Two-stage quantile regression when the first stage is based on quantile regression. The Econometrics Journal, 7(1), 218-231.

Koenker, R. (2004). Quantile regression for longitudinal data. Journal of Multivariate Analysis, 91(1), 74-89.

Koenker, R., \& Bassett Jr, G. (1978). Regression quantiles. Econometrica, 46(1), 33-50.

Koenker, R., \& Hallock, K. F. (2001). Quantile regression. Journal of economic Perspectives, 15(4), 143-156.

Korur, S., Sayın, S., Oğuzalp, E. H., \& Korkmaz, S. Z. (2006). Konutlarda kullanıcı gereksinmelerine bağlı olarak yapılan cephe müdahalelerinin fiziksel çevre kalitesine etkisi. Selçuk Üniversitesi Mühendislik, Bilim ve Teknoloji Dergisi, 21(3), 177-190.

Kostov, P. (2009). A spatial quantile regression hedonic model of agricultural land prices. Spatial Economic Analysis, 4(1), 53-72.

Kördiş, G., Işık S., \& Mert, M. (2014). Antalya'da konut fiyatlarını etkileyen faktörlerin hedonik fiyat modeli ile tahmin edilmesi. Akdeniz Üniversitesi Iktisadi ve Idari Bilimler Fakültesi Dergisi, 14(28), 103-132.

Küçükkaplan, I., \& Amca, A. F. (2017). Denizli ilinde konut fiyatlarına etki eden faktörlerin panel verilerle analizi. Balıkesir Üniversitesi Sosyal Bilimler Enstitüsü Dergisi, 20(37), 219-236.

Lancaster, K. J. (1966). A new approach to consumer theory. Journal of Political Economy, 74(2), 132-157.

Leishman, C. (2001). House building and product differentiation: An hedonic price approach. Journal of Housing and the Built Environment, 16(2), 131-152.

LeSage, J. P., \& Pace, R. K. (2009). Introduction to spatial econometrics. New York: Chapman \& Hall/CRC.

Liao, W. C., \& Wang, X. (2012). Hedonic house prices and spatial quantile regression. Journal of Housing Economics, 21(1), 16-27.

Liu, S., \& Hite, D. (2013, February). Measuring the effect of green space on property value: an application of the hedonic spatial quantile regression. Southern Agricultural Economics Association (SAEA) Annual Meeting.

McGuinness, S., \& Bennett, J. (2007). Overeducation in the graduate labour market: A quantile regression approach. Economics of Education Review, 26(5), 521-531.

Ogutu, J. O., Schulz-Streeck, T., \& Piepho, H. (2012). Genomic selection using regularized linear regression models: Ridge regression, lasso, elastic net and their extensions. BMC Proc, 6(Suppl 2): S10, 1-6.

Ozus, E., Dokmeci, V., Kiroglu, G., \& Egdemir, G. (2007). Spatial analysis of residential prices in Istanbul. European Planning Studies, 15(5), 707-721.

Pavlov, A. D. (2000). Space-varying regression coefficients: A semi-parametric approach applied to real estate markets. Real Estate Economics, 28(2), 249-283.

Rosen, S. (1974). Hedonic prices and implicit markets: Product differentiation in pure competition. Journal of Political Economy, 82(1), 34-55. 
Straszheim, M. R. (1974). Hedonic estimation of housing market prices: A further comment. The Review of Economics and Statistics, 56(3), 404-406.

Sunding, D. L., \& Swoboda, A. M. (2010). Hedonic analysis with locally weighted regression: An application to the shadow cost of housing regulation in Southern California. Regional Science and Urban Economics, 40(6), 550-573.

Tığlı, M., \& Akyazgan, M. A. (2003). Özellikli (lüks) tüketim ürünlerinde enderlik prensibi ve bir uygulama. Kocaeli Üniversitesi Sosyal Bilimler Dergisi, (5), 21-37.

Tobler, W. R. (1979). Cellular geography. S. Gale, G. Olsson (Ed.), Philosophy in Geography içinde (379-386.ss.). Dordrecht; Netherlands: Reidel Publishing Company.

Trzpiot, G. (2012). Spatial quantile regression. Comparative Economic Research, 15(4), 265-279.

Trzpiot, G., \& Orwat-Acedańska, A. (2016). Spatial quantile regression in analysis of healthy life years in the European Union countries. Comparative Economic Research, 19(5), 179-199.

Kangallı Uyar, S. G., \& Yayla, N. (2016). Konut fiyatlarının hedonik fiyatlama yaklaşımına göre mekânsal ekonometrik modeller ile tahmini: İstanbul konut piyasası örneği. Social Sciences (NWSASOS), 11(4), 326-342.

Üçdoğruk, Ş. (2001). İzmir ilinde emlak fiyatlarına etki eden faktörler: Hedonik yaklaşım. Dokuz Eylül Üniversitesi Iktisadi idari Bilimler Fakültesi Dergisi, 16(2), 149-161.

Wen, H. Z., Sheng-hua, J., \& Xiao-yu, G. (2005). Hedonic price analysis of urban housing: An empirical research on Hangzhou, China. Journal of Zhejiang University-Science A, 6(8), 907-914.

Yang, Z., \& Su, L. (2007). Instrumental variable quantile estimation of spatial autoregressive models, Singapore Management University, School of Economics No. 05-2007.

Yayar, R., \& Gül, D. (2014). Mersin kent merkezinde konut piyasası fiyatlarının hedonik tahmini. Anadolu Üniversitesi Sosyal Bilimler Dergisi, 14(3),87-99.

Zietz, J., Zietz, E. N., \& Sirmans, G. S. (2008). Determinants of house prices: A quantile regression approach. The Journal of Real Estate Finance and Economics, 37(4), 317-333.

Zou, H. (2006). The adaptive lasso and its oracle properties. Journal of the American statistical association, 101(476), 1418-1429. 